

\section{DISCLAIMER}

This report was prepared as an account of work sponsored by an agency of the United States Government. Neither the United States Government nor any agency Thereof, nor any of their employees, makes any warranty, express or implied, or assumes any legal liability or responsibility for the accuracy, completeness, or usefulness of any information, apparatus, product, or process disclosed, or represents that its use would not infringe privately owned rights. Reference herein to any specific commercial product, process, or service by trade name, trademark, manufacturer, or otherwise does not necessarily constitute or imply its endorsement, recommendation, or favoring by the United States Government or any agency thereof. The views and opinions of authors expressed herein do not necessarily state or reflect those of the United States Government or any agency thereof. 


\section{DISCLAIMER}

Portions of this document may be illegible in electronic image products. Images are produced from the best available original document. 


\section{Printed in the United States of America. Available from National Technical Information Service \\ U.S. Department of Commerce \\ 5285 Port Royal Road, Springfield, Virginia 22161 \\ Price: Printed Copy $\$ 5.25$; Microfiche $\$ 3.00$}

This report was prepared as an account of work sponsored by an agency of the United States Government. Neither the United States Government nor any agency thereof, nor any of their employees, contractors, subcontractors, or their employees, makes any warranty, express or implied, nor assumes any legal liability or responsibility for any third party's use or the results of such use of any information, apparatus, product or process disclosed in this report, nor represents that its use by such third party would not.infringe privately owned rights. 
Contract No. W-7405-eng-26

FOSSIL ENERGY PROGRAM

PROGRESS REPORT FOR OCTOBER 1978

L. E. McNeese

Date Published - JANUARY, 1979

OAK RIDGE NATIONAL LABORA'TORY

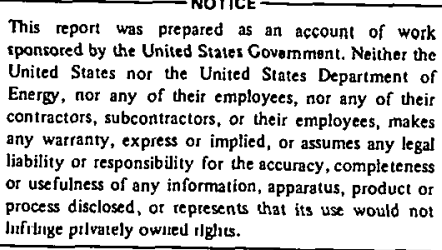

Oak Ridge, Tennessee 37830 operated by UNION CARBIDE CORPORATION

for the DEPARTMENT OF ENERGY 
THIS PAGE

\section{WAS INTENTIONALLY \\ LEFT BLANK}


ABSTRACT . . . . . . . . . . . . . . . . . . . .

1. SUMMARY . . . . . . . . . . . . . . . . . . 1

2. COAL CONVERSION PROCESS DEVELOPMENT . . . . . . . . . . . 4

2.1 Physical Properties of Coal Liquids . . . . . . . . 4

2.2 Coal Slurry Preheaters . . . . . . . . . . . . . . 6

2.3 New Liquefaction Techniques. . . . . . . . . . . . 10

2.4 In-Plant Environmental Monitors. . . . . . . . . . . . . 10

2.5 Experimental Engineering Support of In Situ Gasification Processes .. . . . . . . . . . . 14

2.6 References for Section 2............. 22

3. MATERIALS ENGINEERING . . . . . . . . . . . . . . . . 23

3.1 Pressure Vessel and Piping Materials . . . . . . . . . . 23

3.2 Fossil Energy Welding and Cladding Program . . . . . . 23

3.3 Fireside Corrosion of Atmospheric-Fluidized Bed Combustor Tubes . . . . . . . . . . . . . . . . 24

3.4 Failure Analysis and Prevention ............ . 24

3.5 Materials for $\mathrm{ZnCl}_{2}$ Liquefaction Process Program . . . . 24

3.6 Materials Research for Coal Liquefaction Program . . . . 25

3.7 Development of Advanced 9 Cr-Mo Structural Steel . . . . 25

3.8 Ceramic Recuperators (Heat Exchangers) . . . . . . 25

3.9 References for Section 3.............. 26

4. COAL EQUIPMENT TEST PROGRAM . . . . . . . . . . . . . . . 27

4.1 Coal Feeder Test Program . . . . . . . . . . . . 27

4.2 Survey of Industrial Oapability for Coal Handiling Equipment . . . . . . . . . . . . . 27

4.3 Fossil Fuel Dynamic Equipment Program Plan . . . . . . 28

5. ATMOSPHERIC FLUIDIZED BED COAL COMBUSTOR FOR

COCENERATION (AFBCCC) . . . . . . . . . . . . . . . . . 29

5.1 Objective. . . . . . . . . . . . . . . . . . . . . . . 29

5.2 Status Summary ... . . . . . . . . . . . . 29

5.3 Supplemental Studies ................ 29

6. ENGINEERING STUDIES AND TECHNICAL SUPPORT . . . . . . . . . 30

6.1 Process Modeling . . . . . . . . . . . . . . . 30

6.2 Coal Liquefaction Advanced Research Digest . . . . . . . 31

6.3 Survey of Industrial Coal Conversion Equipment Capabilitiee . . . . . . . . . . . . . . . . . . 31

6.4 Environmental Controls for Low-Btu Gasification . . . . 33

7. PROCESS AND PROGRAM ANALYSIS . . . . . . . . . . . . . . . 34

7.1 In Situ Coal Gasification. . . . . . . . . . . . . . . . 34

7.2 HYGAS Modeling... . . . . . . . . . . . . . 35

7.3 Liquefaction... . . . . . . . . . . . . 35 
7. PROCESS AND PROGRAM ANALYSIS (cont'd)

7.4 High Btu Gas . . . . . . . . . . . . . . . . 36

7.5 Direct Combustion. . . . . . . . . . . . . 39

7.6 Advanced Power Conversion Systems. . . . . . . . . 39

8. FOSSIL ENERGY ENVIRONMENTAL PROJECT . . . . . . . . . . . 40

8.1 Stored Solids Study. . . . . . . . . . . . . . 40

8.2 Technical Assistance . . . . . . . . . . . . . . 41

8.3 Atmospheric Fluidized Bed Combustion Assessment. . . . 42

9. MAGNETIC BENEFICATION OF DRY PULVERIZED COAL. . . . . . . . 43

9.1 Objective. . . . . . . . . . . . . . . . . . . 43

9.2 Status Summary... . . . . . . . . . . . . 43

10. AFBC BENCH SCALE MOUEL. . . . . . . . . . . . . . . . 45

10.1 objective. . . . . . . . . . . . . . . . . 45

10.2 Progress to Date................. . . . . . . 45

11. TENNESSEE VALLEY AUTHORITY (TVA) FLUIDIZED BED COMBUSTION

(FBC) DEMONSTRATION PLANT PROGRAM - TECHNICAL SUPPORT . • •

11.1 Impact of Revised New Source Performance Standards

(NSPS) on AFBC Technology Development - Task 1....

11.2 AFBC Technology Support - Task 2 . . . . . . . . .

11. 3 Assessment of the State-of-the-Art of PFBC

Systems - Task 6 . . . . . . . . . . . . . 
PREVIOUS REPORTS IN THIS SERIES

ORNL/TM-5044, Progress Report for August 1974

ORNL/TM-5045, Progress Report for September 1974

ORNL/TM-5046, Progress Rejort for October 1974

ORNL/TM-4787, Progress Report for November 1974

ORNL/TM-4796, Progress Report for December 1974

ORNL/TM-4850, Progress Report for January 1975

ORNL/TM-4873, Progress Report for February 1.975

ORNL/TM-4892, Progress Report for March 1975

ORNL/TM-4946, Progress Report for April 1975

ORNL/TM-4966, Progress Report for May 1975

ORNL/TM-5010, Progress Report for June 1975

ORNL/TM-5037, Progress Report for July 1975

ORNL/TM-5092, Progress Report for August 1975

ORNL/TM-5124, Progress Report for September 1975

ORNL/TM-5186, Progress Report for October 1975

ORNL/TM-5214, Progress Report for November 1975

ORNL/TM-5246, Progress Report for December 1975

ORNL/TM-5301, Progress Report for January 1976

ORNL/TM-5321, Progress Report for February 1976

ORNL/TM-5430, Progress Report for March 1976

ORNL/TM-5479, Progress Report for April 1976

ORNL/TM-5532, Progress Report for May 1976

ORNL/TM-5595, Progress Report for June 1976

ORNL/TM-5611, Progress Report for July 1976

ORNL/TM-5654, Progress Report for August 1976

ORNL/TM-5674, Progress Report for September 1976

ORNL/TM-5717, Progress Report for October 1976

ORNL/TM-5752, Progress Report for November 1976

ORNL/TM-5770, Progress Report for December 1976

ORNL/TM-5819, Progress Report for January 1977

ORNL/TM-5858, Progress Report for February 1977

ORNL/TM-5883, Progress Report for March 1977

ORNL/TM-5932, Progress Report for April 1977

ORNL/TM-5980, Progress Report for May 1977

ORNL/TM-6003, Progress Report for June 1977

ORNL/TM-6038, Progress Report for July 1977

ORNL/TM-6066, Progress Report for August 1977

ORNL/TM-6104, Progress Report for September 1977

ORNL/TM-61.37, Progress Report for October 1977

ORNL/TM-6217, Progress Report for November 1977

ORNL/TM-6262, Prngress Report for December 1977

ORNL/TM-6274, Progress Report for January 1978

ORNL/TM-6329, Progress Report for February 1978

ORNL/TM-6385, Progress Report for March 1978

ORNL/TM-6386, Progress Report for Apri1 1978

ORNL/TM-6454, Progress Report for May 1978

ORNL/TM-6489, Progress Report for June 1978

ORNL/TM-6518, Progress Report for July 1978 
PREVIOUS REPORTS IN THIS SERIES (CONTINUED)

ORNL/TM-6592, Progress Report for August 1978

ORNL/TM-6630, Progress Report for September 1978 
FOSSIL ENERGY PROGRAM REPORT FOR OCTOBER 1978

\begin{abstract}
This report - the fifty-first of a series - is a compendium. of monthly progress reports for the ORNL research and development programs that are in support of the increased utilization of coal and other fossil fuel alternatives to oil and gas as sources of clean energy. The projects reported this month include those for codl conversion progress development, material engineering, alkali metal vapor topping cycles, a coal equipment test program, an AFB coal combustor for cogeneration (CCC), engineering and support studies, process and program assistance, environmental assessment studies, magnetic beneficiation, and AFBC demonstration plant.
\end{abstract}

\title{
1. Summary
}

L. E. McNeese

Highlights of our progress in October are as follows:

Coal Conversion Development - Progress on Physical Properties of Coal Liquids included the completion of component installation and tie in of the Coal Liquid Flow System to permit shakedown operation and calibration tests. Viscosity determination of flowing coal Iiquid streams at process conditions will receive priority during initial operations. Effort on Coal Slurry Preheaters focused on completion of the preheater test unit and study of fluid flow and liquid holdup in the mock-up unit. Studies of New Liquefaction Techniques have continued in the area of non-catalytic cual depolymcrization In phenn1ic media. High conversion with low phenol consumption has been achieved at relatively mild conditions and short reaction time. The laboratory prototype In-Plant Environmental monitor was successfully tested in coal conversion facilities at ORNL. Two areas of contamination by polynuclear aromatic hydrocarbons were located in the work area which had been previously undetected. The current series of pyrolysis tests with Texas lignite has been completed, and tests with overburden cores have continued in Experimental Engineering Support of In Situ Gasification Processes.

Materials Engineering - Testing to determine the fracture toughness and tensile properties prototypic of thick sections of $21 / 4 \mathrm{Cr}-1$ Mo steel, both unexposed and after exposure to a hydrogen environment, is in progress. An interim report on rapid deposition of sound deposits of type 320 stainless steel on $21 / 4 \mathrm{Cr}-1$ Mo substrates is in progress. Examination of heat exchanger tubes exposed to the 
Fluidyne AFBC for times to $4500 \mathrm{~h}$ is continuing. Corrosion coupons from solvent refined coal plants are being examined to determine the nature of the corrosion products. Construction of facilities to test materials in an environment prototypic of the regenerator of a $\mathrm{ZnCl}_{2}$ coal liquefaction plant is under way. Racks of U-bend samples for exposure in the Fort Lewis, Washington, solvent refined coal plant, have been delivered to the plant. Data on pilot heats of the advanced $9 \mathrm{Cr}$-Mo steel are awaited prior to ordering a large heat of material. Facility modifications to allow testing of ceramic recuperator materials and subcontracts for industrial collaboration, are in progress.

Coal Equipment Test Program - A formal design review of a preliminary feasibility study for a 5 ton/hr coal feeder testing facility was prepared, and completion of the design was approved. Replies to the questionnaires sent to a number of coal handling and ash/slag crushing equipment vendors have been received. Bechtel National has started work on the preparation of conceptual flowsheets for coal conversion plant handling equipment. Initlal activities were directed towards the development of block flowsheets for coarse and fine coal handling operations.

Atmospheric Fluidized Bed Coal Combustor for Cogeneration - The request for proposal has been revised as requested by DOE-FE and Mitre Corporation and was sent to DOE-FE for review.

The tubes from the corrosion test at Fluidyne have been received at ORNL. The appearance of the outer tube surfaces indicates that no serious corrosion has occurred.

Engineering Studies and Technical Support - The latest versions of Purdue's Mass Balance, Energy Balance, and Physical Properties Programs and assoclated documentation have been received at ORNL where processing to Librarian and compiling are being carried out. Example testing is about to commence and results will be reported next month. The costs of several slurry charge pump systems have been evaluated using the 6000 TPD SRC demonstration plant operating conditions as a basis. Although other factors remain to be considered, initial results indicate significant cost advantages accruing to pipe feeder and reciprocating pump feed systems over centrifugal systems of any type.

Process and Program Analysis - Appendices were added to the HYGAS final report (Mathematical Model of the HYGAS P1lot Plant Reactor, ORNL-5475) which document and list the Fortran source program and which present graphical results from the IGT fluid bed model and from a completely backmixed single bed model. At the IGT HYGAS pilot plant, Test Run No. 75 had to be aborted on October 6 due to a leak in the steam/oxygen supply line. Very slight clinker formation was observed in the steam/oxygen gasifier.

In the Fossil Energy Environmental Project, leaching procedures were expanded to include EPA's proposed method as we11 as the two ASTM methods. Technical assistance was provided to DOE/FE on five demonstration plants: Grace; MLGW; ICGG; SRC-I; and SRC-II. This 
included visits by the environmental assessment team to the proposed SRC-I and SRC-II sites. Work continued on the atmospheric fluidized bed combustion assessment.

Magnetic Beneficiation. Float-sink test capability is being added to the laboratory. Ash and bed material from the fluidized bed boiler has been magnetically separated and submitted for chemical analyses. The bulk of the upflow tests at Sala are complete, and the fluidized bed mode of testing has heen initiated.

AFBC Bench Scale Model - Installation of a 10-1n. diam $\times 15-\mathrm{ft}$ tall atmospheric fluidized bed combustor has been completed to the point that shakedown testing with cold air was initiated on November 1 . The shakedown testing will include system checkout, vibration tests with cold air through the empty combustor, air distributor plate pressure drop tests, and cold air fluidizing tests with a limestone bed.

I'VA FBC Demonstration Plant Program - Three tasks have been initiated in this program. A draft brief paper has been prepared in cooperation with TVA to assess the impact of revised new source performance standards in this technology. A preliminary report assessing PFBC technology has been completed in draft form and is currently under review by TVA. A technical review of two documents has been completed and reported to TVA. 


\section{COAL CONVERSION DEVELOPMENT}

H. D. Cochran

Coal conversion development activities are carried out in the Chemical Technology Division. This section discusses four projects conducted for the Division of Fossil Fuel Processing -- Physical Properties of Coal Liquids, Coal Slurry Preheaters, New Liquefaction Techniques, and In-Plant Environmental Monitors -- and one project conducted for the Division of Fossil Fuel Extraction -- Experimental Engineering Support for In-Situ Gasification Processes.

\subsection{Physical Properties of Coal Liquids}

G. E. Oswald, M. R. Gibson, and E. L. Youngblond

Physical properties (viscosity, density, thermal conductivity, and heat capacity) of both coal-solvent slurries and solids-free, coalderived liquids will be measured at typical processing conditions, up to $4500 \mathrm{psig}$ hydrogen pressure and $1000^{\circ} \mathrm{F}$ in a bench-scale, continuous flow system. The system includes a slurry preheater section and a hydrogenation reactor to simulate processing conditions prior to physical property measurement. Immediately after physical property measurement, the test fluids will be quenched and sampled for chemical characterization. Physical properties will be correlated with chemical characteristics of the test liquid.

Work accomplished. The Coal Liquids Flow System pipeline viscometer was used to measure viscosity of light mineral oil at room temperature. The result compared well with measurements made with Brookfield and Cannon-Fenske viscometers. See Section 2.2 of this report for details.

All piping, valves, and instrumentation have been installed to permit liquid to be pumped through the system under pressure. Electrical interconnection of the panel board with the instrument racks is complete.

Preliminary mechanical design for the liquid heat capacity flow calorimeter is complete, Fig. 2.1. Liquid enters the port on the right, flows across a resistance temperature sensor and down through the helical heating section, then up through the center of the helix, past an exit resistance temperature sensor and out the left port. Heat input is via a 0.040 -in.-diam electrical heating element laced through the helical flow section. Typical temperature rise across the instrument is $3^{\circ} \mathrm{F}$. The instrument will be located in a constant temperature bath medium.

Work forecast. Operational checkout of the control panel and automatic shutdown instrumentation will be completed in November and the falling ring viscometer will be installed. After this is completed, the system will be pressurized with nitrogen to check system integrity. 


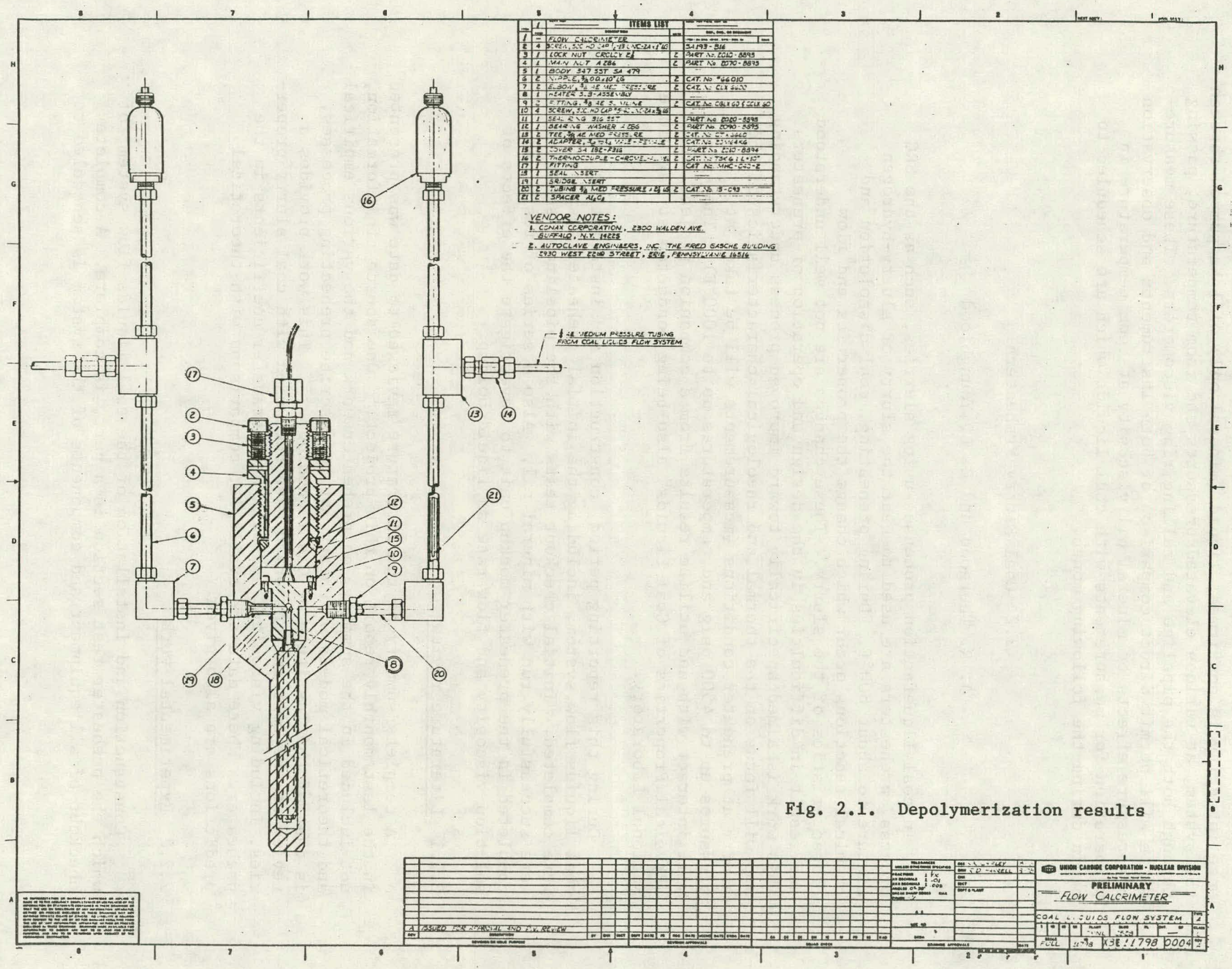


Once integrity is confirmed, liquid (mineral oil) will be pumped through the system, at various elevated pressures and room temperature, passing through both the pipeline and falling ring viscometers. These measurements will permit direct comparison of both instruments and observation of pressure effects on mineral oil viscosity at room temperature in preparation for measurements with coal liquids which are scheduled to begin during the following month.

\subsection{Coal Slurry Preheaters}

J. R. Thurgood and E. L. Youngblood

In coal liquefaction processes using slurries, such as the SRC process, preheaters are used to heat the slurry or slurry-hydrogen mixture to about $800^{\circ} \mathrm{F}$. During preheating, coal dissolution and chemical reactions occur which change the properties and flow characteristics of the slurry. These changes are not well understood and result in difficulties in the design and operation of preheaters. This work is aimed specifically toward improved process understanding and will focus on the thermal and rheological characteristics of the slurry at preheater conditions (measurements will be taken at pressures up to $4500 \mathrm{psig}$ and temperatures up to $1000^{\circ} \mathrm{F}$ ). The effort will interact with and utilize results from a companion project on "Physical Properties of Coal Liquids" also being conducted at Oak Ridge National Laboratory.

During this reporting period, construction and installation of the coal liquids flow system, including the initial preheater test section, were completed. Initial checkout tests with the pipeline viscometer were successfully run with mineral oil. Also a series of tests was completed in the preheater mockup unit to investigate the effects of solution viscosity and flow rate on liquid holdup.

\subsubsection{Literature review}

A complete summary of the literature reviewed to date was presented in the last monthly report on this project. 1 One source of information, not included in the summary, on preheater work and the various empirical and theoretical models which attempt to describe preheating processes, is that of the Institute of Gas Technology. ${ }^{2-4}$ This work provides a review of the correlations which have been used with coal slurry properties, including viscosity, and with heat transfer coefficients in the preheater. Where data are available, comparisons with theoretical predictions are also given.

\subsubsection{Experimental work}

Construction and installation of the coal liquids flow system, of which the preheater test section is a part, is complete. A complete checkout of all equipment and components of the system is scheduled to 
begin immediately. In preparation for the shakedown tests and experimental operations, a safety checklist and a set of operating procedures were written. These will be independently reviewed by a safety committee to ensure proper and safe operation of the facility at high temperatures and pressures.

Initial checkout tests with the installed pipeline viscometer were successfully conducted. Mineral oil was run through the preheater tubing and then through the pipeline viscometer. The oil was not heated nor pressurized above that necessary to pump it through the system. Three parameters were measured for each test, the liquid flow rate, the pressure drop across the viscometer, and the temperature of the oil, which essentially remained constant at $23^{\circ} \mathrm{C}$. The independent variable was the liquid or oil flow rate. The resulting data were plotted as:

$\mathrm{D} \Delta \mathrm{P} / 4 \mathrm{~L}$ vs. $8 \mathrm{~V} / \mathrm{D}$

where: $\mathrm{D}=$ inside diameter of the viscometer tube

$\mathrm{L}=$ length of the viscometer tube

$\Delta \mathrm{P}=$ pressure drop across the viscometer

$\mathrm{V}=$ velocity of the liquid through the viscometer.

The velocity of the liquid was determined from the flow rate and tube diameter. It is noted that the shear stress at the tube wall $\left(\tau_{w}\right)$ can be shown to be equal to $\mathrm{D} \Delta \mathrm{P} / 4 \mathrm{~L}$. Fig. 2.2 presents a plot of $\mathrm{D} \Delta \mathrm{P} / 4 \mathrm{~L}$ vs. $8 \mathrm{~V} / \mathrm{D}$. Rabinowitsch and Mooney 5 have shown that such a plot can be used to characterize the rheological behavior of the liquid. For Newtonian fluids the plot results in a straight line with a slope of one, as is the case for the mineral oil plot of Fig. 2.2. For Newtonian fluids the viscosity $(\mu)$ becomes $\left(\tau_{w}\right) /(8 \mathrm{~V} / \mathrm{D})$. In the case of the tested mineral oil, the viscosity was determined to be $85 \mathrm{cp}$ which compared to $81 \mathrm{cp}$ and $90 \mathrm{cp}$ as determined by a Brookfield viscometer and a Cannon-Fenske viscometer respectively. Fluids other than mineral oil will be tested in the pipeline viscometer to further check out its use and to determine the range of pressure drop across the viscometer.

Tests were continued with the preheater mockup unit to determine the flow regime and to measure the liquid holdup as a function of liquid flow rate and liquid viscosity. Three different concentrations of glycerol/water solutions, with viscosities of $53 \mathrm{cp}, 130 \mathrm{cp}$, and $418 \mathrm{cp}$, were used in the experiments. Fig. 2.3 shows the plot of liquid holdup vs. gas flow rate for two different liquid flow rates. As expected, as the liquid flow rate is increased, the liquid holdup is also increased. In the preheater, typical gas flow rates will be on the order of 10 times the liquid flow rate. Therefore, from the data plotted in Fig. 2.3, it is seen that liquid holdup in the preheater may be as high as 0.6 . The effect of viscosity on the extent of liquid holdup at high gas flow rates seems to be small. Tests were conducted on each of the three different viscosity solutions. At gas flow rates of 10 times or more than those of liquid flow rates, liquid holdup was consistently around 0.52 regardless of the viscosity $(53 \mathrm{cp}-418 \mathrm{cp})$. 


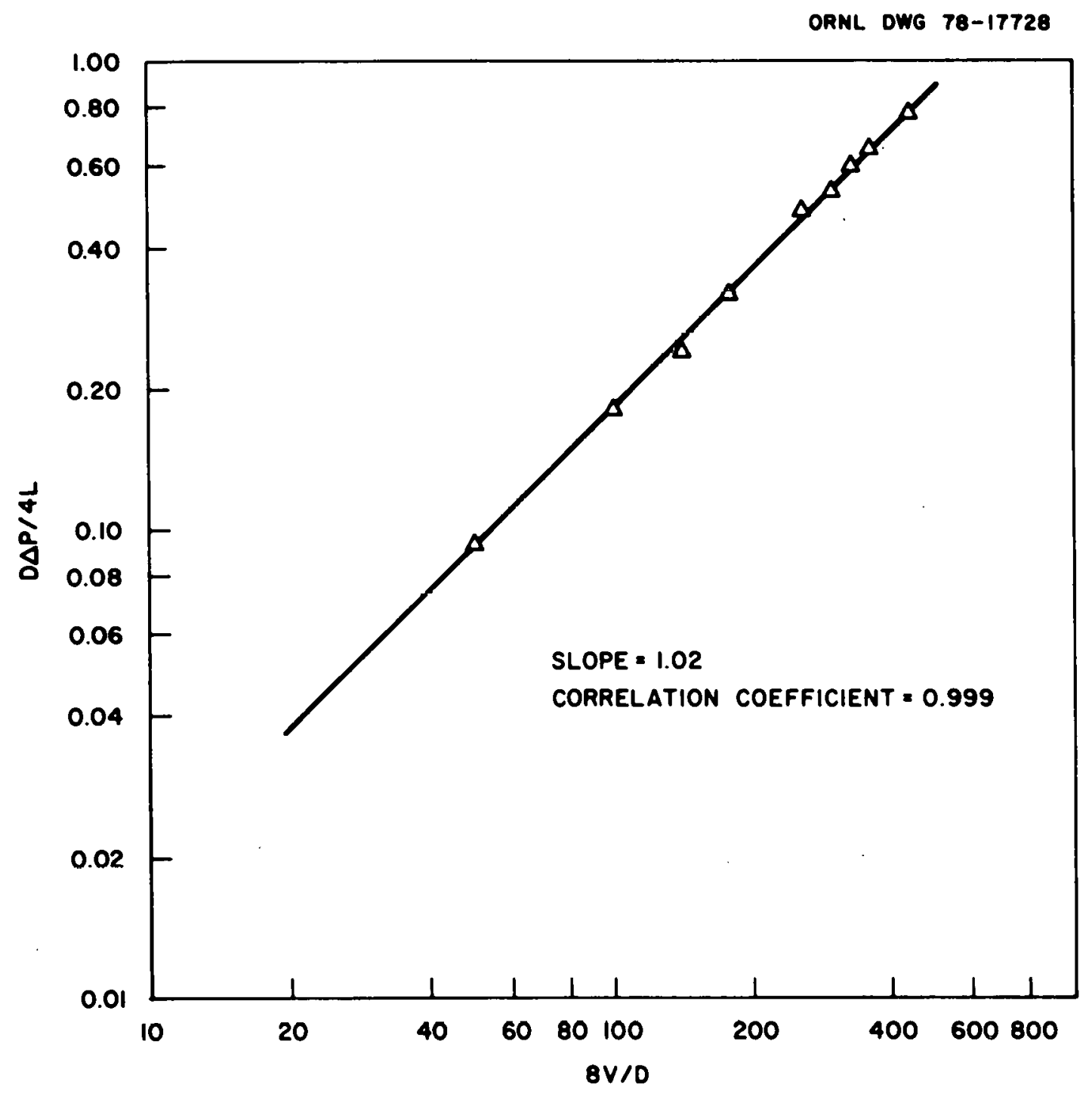

Fig. 2.2. Plot of $\mathrm{D} \Delta \mathrm{P} / 4 \mathrm{~L}=\tau_{\mathrm{w}}$ vs. $8 \mathrm{~V} / \mathrm{D}$. 
ORNL DWG 78-17729

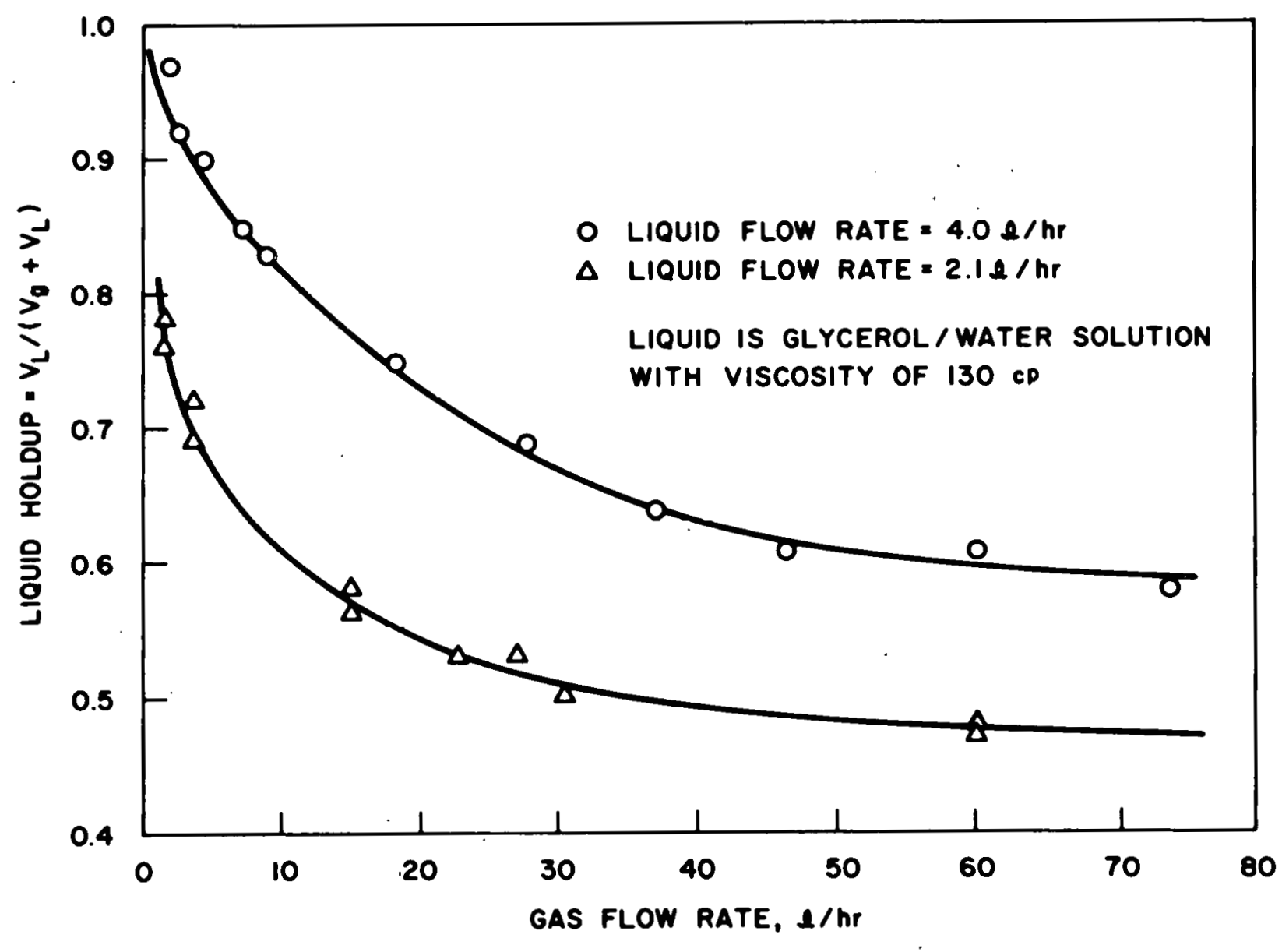

Fig. 2.3. Liquid holdup vs. gas flow rate. 


\subsubsection{Work forecast}

Work scheduled during the next reporting period includes (1) continuation of tests with the pipeline viscometer, (2) initiation of checkout tests on all facility equipment and components, and (3) operation of the preheater mockup unit with recycle solvent and coal/solvent slurries.

\subsection{New Liquefaction Techniques \\ J. W. Larsen and H. D. Cochran, Jr.}

Exploratory studies are being conducted in an effort to identify possible new techniques for liquefying coal. Current efforts are focused on the non-catalyzed depolymerization of coal using phenol and phenolic compounds without hydrogen overpressure. Efforts on the acid catalyzed ionic hydrogenation and Heredy-Neuworth depolymerization have been curralled.

Results obtained during the last month are reported in Table 2.1. Run No. 18 is especially interesting. It utilized a higher phenol/coal ratio than normal, a situation already known to give high conversions. Combining a high phenol/coal ratio with better, although still not good, mixing gives attractive conversion levels. An apparatus which will shake the reactors violently in the heating bath is being designed.

Comparing Run No. 15 with previous data shows that the coal first loses weight and its extractability actually decreases. However, with continued heating phenol is incorporated and the extractability increases. The original weight loss may be due to pyrolysis or extraction.

Comparing Run No. 17 with two earlier runs shows that the conversion of Wyodak is about the same at $850^{\circ}$ and $900^{\circ} \mathrm{F}$, but the phenol incorporation is much less at $850^{\circ}$, making this temperature more desirable.

Prospects for this approach to coal conversion are favorable enough so that a detailed chemical examination of the soluble products has begun.

\subsection{In-Plant Environmental Monitors \\ D. D. Schuresko and G. Jones, Jr.}

During the month of October, we carried out laboratory measurements to determine the sensitivity of the prototype spotter to various coal conversion products and wastes. These results are listed in Tables 2.2 and 2.3. These data were determined by normalizing the measured fluorescence of 1-10 mgm samples by the measured background noise and the amount of material in each sample, and thus are upper limits on the actual sensitivities. The prototype, therefore, has ample sensitivity to detect minute amounts of PNAs in various coal materials. 
Table 2.1. Depolymerization results

\begin{tabular}{|c|c|c|c|c|c|c|c|}
\hline $\begin{array}{l}\text { Run } \\
\text { No. }\end{array}$ & $\begin{array}{c}\text { Coal } \\
\text { (wt. g) }\end{array}$ & $\begin{array}{l}\text { Weight } \\
\text { phenol } \\
(g)\end{array}$ & $\begin{array}{c}\text { Run } \\
\text { temperature } \\
\left({ }^{\circ} \mathrm{F}\right)\end{array}$ & $\begin{array}{l}\text { Run } \\
\text { time } \\
\text { (min) }\end{array}$ & $\begin{array}{l}\text { Weight } \\
\text { increase } \\
(\%)\end{array}$ & $\begin{array}{c}\text { Pyridine } \\
\text { extractability } \\
(\%)\end{array}$ & Comments \\
\hline 13 & Wyodak :2.61) & 14.6 & 850 & 5 & 6.9 & 32.1 & \\
\hline 14 & Bruceton (2.58) & & 800 & 5 & $>36$ & 33.5 & $8.7 \mathrm{~g}$ of hydroquinone $\mathrm{tsed}$ \\
\hline 15 & Bruceton (2.64) & 14.6 & 800 & 5 & -6.1 & 14.4 & \\
\hline 16. & Wyodak $: 2.61)$ & 14.6 & 800 & 18 & NA & 26.0 & 011 lost \\
\hline 17 & Wyodak $(7.80)$ & 40.8 & 900 & 6 & 15.5 & 31 & $\begin{array}{l}\text { Large bomb used, } \\
\mathrm{T} \text { very uncertain }\end{array}$ \\
\hline 18 & Wyodak (0.69) & 10.1 & 800 & 10 & -13 & 64.3 & Shaken thoroughly \\
\hline
\end{tabular}


Table 2.2. Sensitivity to various substances

(Excitation $=350 \mathrm{~nm}$, Emission cut-on $=420 \mathrm{~nm}$ )

\begin{tabular}{lcc}
\hline \multicolumn{1}{c}{ Sample } & $\begin{array}{c}\text { Sensitivity } \\
\text { (Milligrams) }\end{array}$ & $\begin{array}{c}\text { Distance } \\
(\mathrm{cm})\end{array}$ \\
\hline $\mathrm{HC}-10$ scrubber $\mathrm{H}_{2} \mathrm{O}$ & 1.0 & 22 \\
$\mathrm{HC}-8$ bioreactor feed & 10.0 & 22 \\
$\mathrm{~W}-41$ bioreactor effluent & 250.0 & 22 \\
$\mathrm{UNH}\left(\mathrm{UO}_{2}\left(\mathrm{NO}_{3}\right)_{2} \cdot 6 \mathrm{H}_{2} 0\right)$ & 1.0 & 27 \\
Perylene & .001 & 82 \\
\hline
\end{tabular}


Table 2.3. Sensitivity to various substances (Excitation $=350 \mathrm{~nm}$, Emission $=520 \mathrm{~nm}$, Distance $=60 \mathrm{~cm}$ )

\begin{tabular}{lc}
\hline \multicolumn{1}{c}{ Sample * } & $\begin{array}{c}\text { Sensilivity } \\
\text { (Micrograms) }\end{array}$ \\
\hline SRC-I recycle solvent & 27 \\
SRC-I wash solvent & 129 \\
SRC-I process solvent & 34 \\
SRC-I light organic liquid (raw) & 884 \\
SRC-II fuel oil blend & 17 \\
Centrifuged shale oil (process I) & 26 \\
Hydrotreated coal distillatc & 38 \\
Product distillate (ZnCl ${ }_{2}$ ) & 11 \\
COED Syncrude & 20 \\
ORNL hydrocarbonization oil (HC-12) & 790 \\
\hline
\end{tabular}

* Samples were 1-20 micron thick films on microscope slides under cover sili.ps. 
We have also satisfactorily operated the prototype spotter in the ORNL Hydrocarbonization Facility and were able to detect contamination on and around the gas scrubber unit. Additional monitoring there is planned for the near future.

\subsection{Experimental Engineering Support of In Situ Gasification Processes}

P. R. Westmoreland, L. S. Dickerson, and B. R. Rodgers

Experiments and analyses continued during this quarter to expand the understanding of physical processes and reactions in underground coal gasification (UCG). Items discussed in this report are:

- Experiment BP2-56, lignite block pyrolysis at $3^{\circ} \mathrm{C} / \mathrm{min}$ to $600^{\circ} \mathrm{C}$ in inert gas,

- Relative pyrophoricities of lignite char blocks,

- Chemical analysis, physical properties, and yields from heating of a claystone overburden (Hoe Creek site).

This research program supports both the modeling and field development of in situ (or underground) coal gasification, and emphasizes study of the pyrolysis of large coal blocks. Pyrolysis of overburden are also part of the program. Block pyrolysis data are valuable for. modeling of in situ coal gasification because previous pyrolysis data have described only the pyrolysis of powder samples. By contrast, large masses of coal react during UCG, either as large blocks or as a seam cross-section. In both cases, internal heat and mass transfer resistances become more important in situ than during powder pyrolysis, and product yields can change significantly.

In experiments which began at ORNL in 1975, 6-in.-diam (15-cm) right circular cylinders of lignite, subbituminous coal, and bituminous coal have been pyrolyzed by heating the blocks at $0.3-14^{\circ} \mathrm{C} / \mathrm{min}$ (surface temperature) from ambient temperature to maximum temperatures of $500-$ $1000^{\circ} \mathrm{C}$. Using an inert (argon) or reducing (hydrogen) purge gas at atmospheric pressure, gas- and vapor-phase reaction products are continuously swept from the reactor. Water, oils, and tars are collected in a water-cooled condenser and by filters, and the remaining noncondensible gases are metered and periodically sampled. In many of the experiments, block temperature profiles have been measured by internal thermocouples. These tests are designed to support modeling of field UCG experiments by Laramie Energy Technology Center (LETC), Lawrence Livermore Laboratory (LLL), and Morgantown Energy Technology Center (METC). 


\subsubsection{Lignite block pyrolysis and pyrophoricity}

Experiment BP2-56, conducted during this reporting period, is the last regularly-scheduled experiment in a series of lignite block pyrolyses in inert and $\mathrm{H}_{2}$ purge gas. This series of experiments BP2-46 through BP2-56 is the minimum number needed to describe effects of heating rate $\left(0.3,3\right.$, and $\left.10^{\circ} \mathrm{C} / \mathrm{min}\right)$, maximum temperature $\left(600,800\right.$, and $\left.1000^{\circ} \mathrm{C}\right)$, water content (natural content of $37 \% \mathrm{H}_{2} \mathrm{O}$ or dried), and the two purge gases. In BP2-56, the block surface was heated at $3^{\circ} \mathrm{C} / \mathrm{min}$ to $1000^{\circ} \mathrm{C}$ in inert gas; other experimental conditions for the series are summarized in Table 2.4 .

Pyrophoric lignite chars were observed in nearly all experiments. For lignite and lignite chars, pyrophoricity or spontaneous ignition is a widely-recognized phenomenon associated with generally high reactivities of these materials. Hippo and Walker 6 have measured the increasing reactivity of chars to air and $\mathrm{CO}_{2}$ as a function of decreasing rank and have attributed the increase to: (1) better mass transport of $\mathrm{O}_{2}$ to reactive sites because of greater macropore volume and (2) to more catalytic mineral matter, primarily $\mathrm{Ca}$ and $\mathrm{Mg}$. More recently, reactivity of lignite char to air was shown to decrease when small amounts of carbon are deposited by cracking of volatile pyrolysis products. 7

To compare relative reactivity of chars from recent experiments, initial heating rates after air exposure were measured. The cooled block of char was raised from the Ar-filled reactor into the air, and a thermocouple positioned $13 \mathrm{~mm}$ (1/2 in.) from the block center was monitored. After the block had begun to heat, it was lowered back into $\mathrm{Ar}$ and the burning was quenched. The resulting data are compared in Table 2.5 with respect to variation in conditions of char preparation (block pyrolysis): surface heating rate, maximum temperature, purge gas, and coal moisture content.

Effects of block heating rate on pyrophoricity of the resulting char may be explained on the basis of carbon deposition in the pores. It has been shown 8 that steep temperature gradients within the block (created by hlylıer surface heating rates) apparently cause secondary cracking ot pyrolysis products, particularly of oils. Kamishita, Mahajan, and Walker ${ }^{7}$ demonstrated that carbon deposition at the mouths of micropores could result from cracking of $\mathrm{CH}_{4}\left(815-855^{\circ} \mathrm{C}\right)$, decreasing the reactivity of lignite char to air. Secondary cracking reactions of oils within the block probably cause similar carbon deposits, linking higher heating rates during block pyrolysis to decreased reactivity.

Reasons for the effects of other variables on pyrophoricity are not apparent. For Ar-purged experiments at constant heating rate, data suggest that maximum pyrophoricity occurs between 600 and $1000^{\circ} \mathrm{C}$; data from $\mathrm{H}_{2}$-purged experiments agree that any maximum would occur above $600^{\circ} \mathrm{C}$. If a maximum occurs, it may be the result of increased carbon deposition at higher temperatures. Secondly, limited data indicate that chars prepared in reducing gas $\left(\mathrm{H}_{2}\right)$ are less reactive than chars 
Table 2.4. Summary of experimental conditions for pyrolysis experiments using lignite blocks

\begin{tabular}{|c|c|c|c|c|c|c|c|c|c|}
\hline \multirow{3}{*}{$\begin{array}{l}\text { Run } \\
\text { number }\end{array}$} & \multirow{3}{*}{$\begin{array}{l}\text { Date of } \\
\text { run }\end{array}$} & \multirow{3}{*}{$\begin{array}{l}\text { Heating } \\
\text { rate } \\
\left({ }^{\circ} \mathrm{C} / \mathrm{min}\right)\end{array}$} & \multirow{3}{*}{$\begin{array}{c}\text { Maximum } \\
\text { temperature } \\
\left({ }^{\circ} \mathrm{C}\right)\end{array}$} & \multicolumn{2}{|r|}{ Purge gas } & \multicolumn{4}{|c|}{ Coal block ${ }^{\mathbf{a}}$} \\
\hline & & & & \multirow[b]{2}{*}{ Gas } & \multirow{2}{*}{$\begin{array}{c}\text { Flow rate } \\
\text { (Std. liter/min) }\end{array}$} & \multicolumn{2}{|c|}{ Dimensions $(\mathrm{cm})$} & \multicolumn{2}{|c|}{ Weight } \\
\hline & & & & & & Height & Diameter & $\overline{(\mathrm{kg})}$ & $(\mathrm{kg}$ maf) \\
\hline BP 2-46 & $3 / 31 / 78$ & 3 & 800 & $\mathrm{H}_{2}$ & 2.87 & 15.9 & 13.5 & 3.609 & 1.957 \\
\hline BP 2-47 & $4 / 21 / 78$ & 3 & 1000 & $\mathrm{H}_{2}$ & 2.90 & 17.5 & 15.1 & 3.921 & 2.126 \\
\hline BP 2-48 & $5 / 4 / 78$ & 3 & 600 & $\mathrm{H}_{2}$ & 2.828 & 16.8 & 14.9 & 3.743 & 2.030 \\
\hline BP2-49 & $5 / 15 / 78$ & 0.3 & 800 & $\mathrm{H}_{2}$ & 2.993 & 19.4 & 15.1 & 4.319 & 2.342 \\
\hline BP2-50 & $5 / 26 / 78$ & 9 & 800 & $\mathrm{H}_{2}$ & 2.775 & 18.4 & 14.6 & 3.927 & 2.129 \\
\hline BP 2-51 & $6 / 12 / 78$ & 0.3 & 800 & Ar & 3.056 & 17.9 & 14.6 & 4.085 & 2.215 \\
\hline BP 2-52 & $6 / 26 / 78$ & 3 & $800^{b}$ & Ar & 3.428 & 20.2 & 14.9 & 4.555 & 2.470 \\
\hline BP $2-53$ & $7 / 12 / 78$ & 10 & 800 & Ar & 3.016 & 20.3 & 14.9 & 4.558 & 2.471 \\
\hline BP 2-54 & $8 / 4 / 78$ & 3 & 800 & Ar & 3.022 & 18.9 & 15.1 & 4.342 & 2.354 \\
\hline BP 2-55 & $8 / 30 / 78$ & 3 & 1000 & Ar & 2.921 & 19.8 & 14.9 & 4.497 & 2.438 \\
\hline BP2-56 & $10 / 18 / 78$ & 3 & 600 & Ar & 2.800 & 18.7 & 15.2 & 3.939 & 2.136 \\
\hline
\end{tabular}

axperiments have used lignite from the Calvert Bluff formation of the Wilcox group, Sandow Mine (Milam County, Texas).

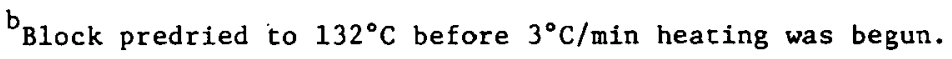


Table 2.5. Effects of experimental variables on the pyrophoricity of lignite chars

\begin{tabular}{|c|c|c|c|c|}
\hline \multirow[b]{3}{*}{ Conparison } & \multicolumn{2}{|c|}{ Char preparation conditions } & \multirow{2}{*}{\multicolumn{2}{|c|}{$\begin{array}{l}\text { Pyrophoricity: Initial rate } \\
\text { of self-heating }\left({ }^{\circ} \mathrm{C} / \mathrm{min}\right)\end{array}$}} \\
\hline & Reactor & Maximum & & \\
\hline & $\begin{array}{l}\text { heating rate } \\
\left({ }^{\circ} \mathrm{C} / \mathrm{min}\right)\end{array}$ & $\begin{array}{l}\text { temperature } \\
\quad\left({ }^{\circ} \mathrm{C}\right)\end{array}$ & $\begin{array}{l}\text { Char prepared } \\
\text { in } \mathrm{Ar}\end{array}$ & $\begin{array}{l}\text { Char prepared } \\
\text { in } \mathrm{H}_{2}\end{array}$ \\
\hline \multirow{3}{*}{$\begin{array}{l}\text { Effect of surface heating rate } \\
\text { (steepness of internal temperature } \\
\text { gradients) }\end{array}$} & 0.3 & 800 & 7.9 & $-{ }^{a}$ \\
\hline & 3 & 800 & 5.09 & 1.76 \\
\hline & 10 & 800 & 3.74 & $<0.1$ \\
\hline \multirow[t]{3}{*}{ Effect of maximum temperature } & 3 & 600 & 2.14 & 0.26 \\
\hline & 3 & 800 & 5.09 & 1.76 \\
\hline & 3 & 1000 & 0.73 & $-{ }^{a}$ \\
\hline \multirow{3}{*}{$\begin{array}{l}\text { Effect of purge gas (inert gas } \\
\text { vs. } \mathrm{H}_{2} \text { ) }\end{array}$} & 3 & 600 & 2.14 & 0.26 \\
\hline & 3 & 800 & 5.09 & 1.76 \\
\hline & 10 & 800 & 3.74 & $<0.1$ \\
\hline \multirow{2}{*}{$\begin{array}{l}\text { Effect of coal moisture (predried } \\
\text { vs. wet block) }\end{array}$} & 3 & 800 & $12.8^{\mathrm{b}}$ & - \\
\hline & 3 & 800 & 5.09 & - \\
\hline
\end{tabular}

$\mathrm{a}_{\mathrm{B} \text { lock }}$ collapsed during removal; no data.

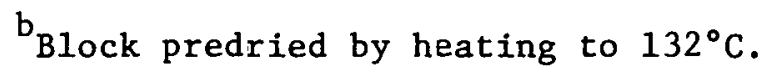


prepared in inert gas. Earlier data from block pyrolysis of bituminous coal 8 suggest that more secondary cracking takes place in $\mathrm{H}_{2}$ than in $\mathrm{Ar}$, so carbon deposits could again account for decreased pyrophoricity. Finally, predrying of coal produced a char that was twice as reactive as char prepared from naturally wet coal at otherwise identical conditions.

\subsubsection{Pyrolysis and property measurements of overburden}

A cored sample of claystone overburden was tested in experiment OB-3 during the past month. Sampled from the LLL Hoe Creek II site (well SS-2), this core was nominally very similar to the claystone tested in experiments $\mathrm{OB}-1$ and $\mathrm{OB}-2$ (see comparison in Table. 2.6). Since the sample was heated at $3^{\circ} \mathrm{C} / \mathrm{min}$ to $1000^{\circ} \mathrm{C}$ and since internal temperature gradients were comparable, yields would be expected to be nearly the same as the combined ylelds from $O B-1$ and $O B-2$.

Some characterization data on the $\mathrm{OB}-3$ sample are presented in Table 2.7. Moisture was measured by drying in a vacuum oven at $107^{\circ} \mathrm{C}$, and carbon and hydrogen were measured as indicators of organic content. Bulk density of the wet solid was determined by pycnometer to be 2.24 $\mathrm{g} / \mathrm{cm}^{3}$. No shrinkage was measured after drying, so bulk density of the dry overburden is $1.94 \mathrm{~g} / \mathrm{cm}^{3}$.

Preliminary yield data from $\mathrm{OB}-1,-2$, and -3 indicate some differences in the decomposition of the two samples (Table 2.8). From comparison of estimated gas yield to preliminary data, material balance closure seems satisfactory. Heating of the similar materials produced more solid residue and less gas from sample 48 than from sample 49. No oils and tars were detected, so the small amount of organic matter decomposed to produce primarily char, $\mathrm{H}_{2}, \mathrm{CH}_{4}, \mathrm{CO}_{2}$, and $\mathrm{CO}$. Most of the $\mathrm{CO}_{2}$ was probably produced from decomposition of carbonates.

\section{5 .3 Future plans}

Overburden tests in the block pyrolysis reactor will continue to provide data on chemical and physical properties of field samples. In addition, a series of experiments will begin in which lignite, subbituminous coal, and bituminous coal blocks will be pyrolyzed in a simulated UCG product gas. From review of past Wilcox lignite experiments, correlations of yields will be developed similarly to those developed for Pittsburgh bituminous coal. 
Table 2.6. Description of samples for overburden experiments (ref. 9)

\begin{tabular}{|c|c|c|c|c|}
\hline \multirow[b]{2}{*}{$\begin{array}{c}\text { Run } \\
\text { number }\end{array}$} & \multirow[b]{2}{*}{ Source } & \multicolumn{2}{|c|}{ Location } & \multirow[b]{2}{*}{ Characteristics } \\
\hline & & $\begin{array}{l}\text { Depth in } \\
\text { well (m) }\end{array}$ & $\begin{array}{c}\text { Height above } \\
\text { coal }(\mathrm{m})\end{array}$ & \\
\hline $\mathrm{OB}-1$ & $\begin{array}{l}\text { LLL Hoe Creek } 2 \text { site; } \\
\text { wel1 SS-2, sample } 48\end{array}$ & 28.1 & $\begin{array}{r}2.0(\text { Felix No. } 1) \\
11.0(\text { Felix No. } 2)\end{array}$ & $\begin{array}{l}\text { Slightly silty clay- } \\
\text { stone: light brown to } \\
\text { light black, slightly } \\
\text { carbonaceous, thin- } \\
\text { bedded }\end{array}$ \\
\hline $\mathrm{OB}-2$ & $\begin{array}{l}\text { LLI Hoe Creek } 2 \text { site; } \\
\text { well SS-2, sample } 48 \\
\text { (used dried rock from } \\
\text { expt. OB-1) }\end{array}$ & 28.1 & $\begin{array}{r}2.0(\text { Felix No. } 1) \\
11.0(\text { Felix No. } 2)\end{array}$ & $\begin{array}{l}\text { Slightly silty clay- } \\
\text { stone: light brown to } \\
\text { light black, slightly } \\
\text { carbonaceous, thin- } \\
\text { bedded }\end{array}$ \\
\hline$O B-3$ & $\begin{array}{l}\text { LLL Hoe Creek } 2 \text { site; } \\
\text { wel1 SS-2, sample } 49\end{array}$ & 28.4 & $\begin{array}{r}1.7 \text { (Felix No. } 1) \\
10.7 \text { (Felix No. } 2)\end{array}$ & $\begin{array}{l}\text { Slightly silty clay- } \\
\text { stone: light brown to } \\
\text { light black, slightly } \\
\text { carbonaceous, thin- } \\
\text { bedded }\end{array}$ \\
\hline
\end{tabular}


Table 2.7. Analyses of $O B-3$ overburden sample

\begin{tabular}{lc}
\hline \multicolumn{1}{c}{ Analysis } & Data \\
\hline (1) Moisture (\%) & 13.3 \\
(2) Carbon (\% moisture-free) & $3.63^{\mathrm{a}}$ \\
(3) Hydrogen (\% moisture-free) & 0.06 \\
(4) Bulk density of wet solid $\left(\mathrm{g} / \mathrm{cm}^{3}\right)$ & 2.24 \\
(5) Shrinkage after drying (\%) & None \\
(6) Bulk density of dry solid & 1.94 \\
& $\begin{array}{l}\left.\mathrm{g} / \mathrm{cm}{ }^{3}, \text { and } 5\right) \\
\text { (5) }\end{array}$ \\
\hline
\end{tabular}

ancludes carbon in carbonates. 
Table 2.8. Comparison of yields from slightly carbonaceous claystone

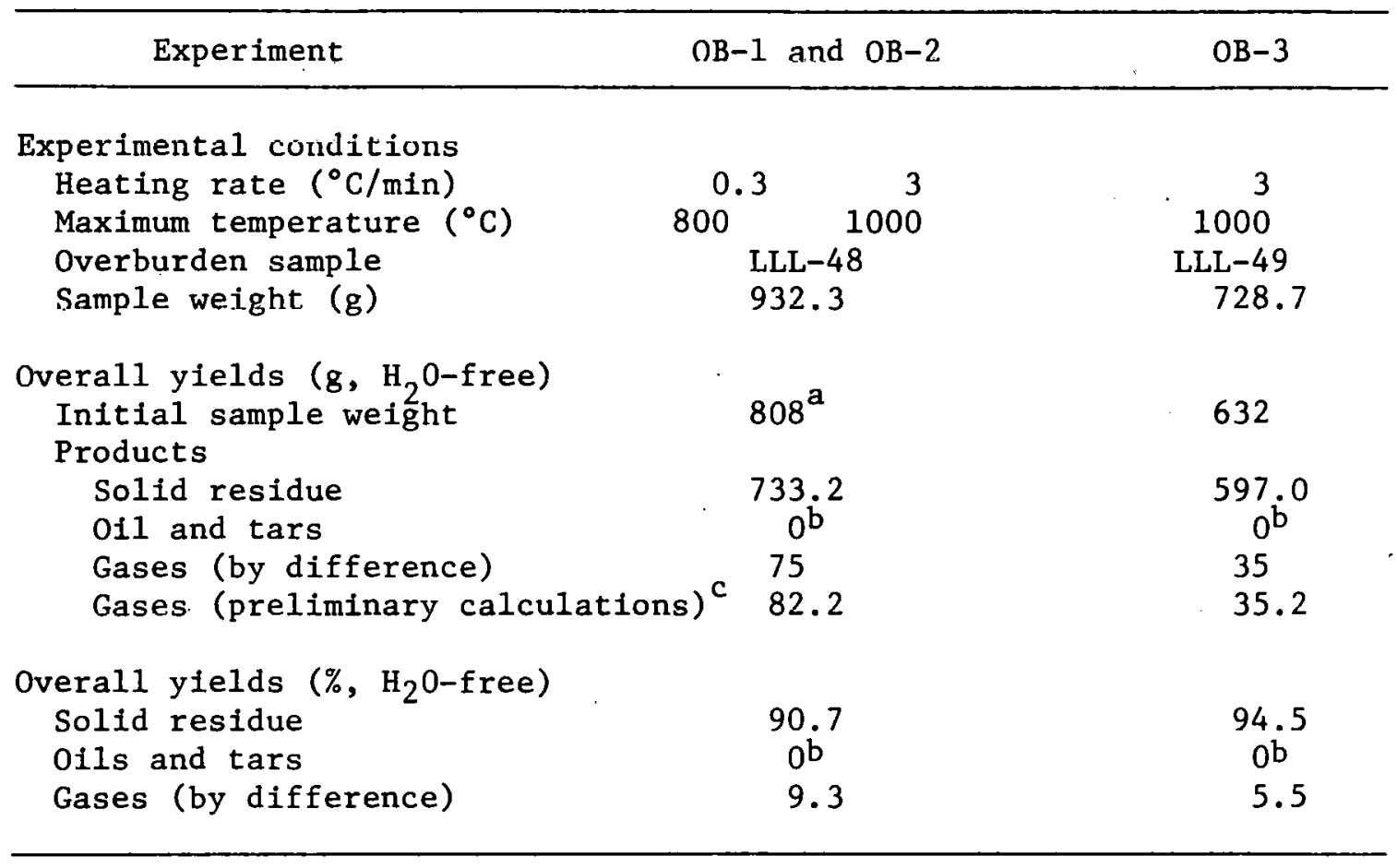

assumes $13.3 \%$ moisture, same as sample LLL-49.

${ }^{b}$ Not detected.

${ }^{c}$ Predominantly $\mathrm{CO}_{2}$ (approximately $20 \mathrm{std}$. $\mathrm{l} / \mathrm{kg} \mathrm{mf}$ ) with $\mathrm{Co}, \mathrm{H}_{2}, \mathrm{CH}_{4}$, and $\mathrm{C}_{2}$ 's also detected. 


\subsection{Refcrences for Section 2}

1. Fossil Energy Program Progress Report for September 1978, ORNL/TM-5487, Oak Ridge National Laboratory, Oak Ridge, Tennessee (in publication).

2. Preparation of a Coal Conversion Systems Technical Data Book, Project 8979 Annual Report, May 1, 1976 - April 30, 1977, FE-2286-16, Institute of Gas Technology, Chicago, I11. (Jan. 1978).

3. Preparation of a Coal Conversion Systems Technical Data Book, Project 8979 Quarter1y Report, May 1 - July 31, 1977, FE-2286-20, Institute of Gas Technology, Chicago, Ill. (Jan, 1978).

4. Preparation of a Coal Conversion Systems Technical Data Book, Project 8979 Quarterly Report, August 1 - October 31, 1977, FE-2286-24, Institute of Gas Technology, Chicato, I11. (Feb. 1978).

5. G. W. Govier and K. Az1z, The Flow of Complex Mixtures in Pipes, Van Nostrand Reinhold Co., New York, N.Y., pp. 183-185 (1972).

6. E. Hippo and P. L. Walker, Jr., Fuel, 54, pp. 245-248 (October 1975).

7. M. Kamishita, O. P. Mahajan, and P. L. Walker, Jr., Fuel, 56, pp. 444-450 (October 1977).

8. P. R. Westmoreland, "Pyrolysis of Bituminous Coal Blocks," Proceedings of the $4 \mathrm{th}$ Underground Coal Conversion Symposium, Sandia Laboratories report SAND 78-0941 (June 1978).

9. H. C. Ganow, Lawrence Livermore Laboratory, personal communication to P. R. Westmoreland, October $11,1978$. 


\section{MATERIALS ENGINEERING}

R. T. King

The materials engineering and associated technology reported here are in support of activities directed or coordinated by the Materials Engineering Research Branch, Division of Systems Engineering, Fossil Energy. Other related work funded by the Division of Fossil Fuel Utilization and the Division of Fossil Fuel Processing is a1so included.

\subsection{Pressure Vessel and Piping Materials}

W. J. Stelzman, R. 0. Williams, and D. A. Canonico

The heat treatment and testing of material from the SA 387, Grade 22 plate (2 $1 / 4 \mathrm{Cr}-1 \mathrm{Mo})$ is continuing in various stages of preparation. Charpy specimens from bars which have been fast- or slow-cooled $(3 \mathrm{~K} / \mathrm{s}$ or $0.3 \mathrm{~K} / \mathrm{s}$ ) from $972^{\circ} \mathrm{C}$ or fast-cooled $(3 \mathrm{~K} / \mathrm{s})$ from $1038^{\circ} \mathrm{C}$, then tempered and stress relieved for $120 \mathrm{~h}[\mathrm{~T}+\mathrm{SR}(120)]$, are being fatigue precracked and will be ready for testing shortly to determine static fracture toughness properties.

Specimen bars which have been slow-cooled from $1038^{\circ} \mathrm{C}$ and T + SR (120), together with extra specimen bars which duplicate previous heat treatments, are ready for machining into test specimens. An additional group of specimen bars which have been slow- or fast-cooled from $1038^{\circ} \mathrm{C}$ and $\mathrm{T}+\mathrm{SR}(40)$ are being aged at $343^{\circ} \mathrm{C}$ for $1000 \mathrm{~h}$ and will be completed in mid-December. These bars will be included with the previous group and machined into specimens.

The equipment for exposing steels to high pressure hydrogen at elevated temperatures has been installed and is being checked out. Specifically, we have a run in progress which has the expressed purpose of verifying that we can use high temperature strain gages for monitoring the degree of attack. No problems have been encountered.

\subsection{Fossil Energy Welding and Cladding Program \\ D. P. Edmonds, J., J. Woodhouse, and J. D. Hudson}

A report entitled Submerged-Arc and Gas Metal-Arc Cladding of 2 1/4 Cr-1 Mo Steels with Type 320 Stainless Steel, is in preparation. Supplemental work continues in support of the conclusions drawn in this work, that nickel content of the weld deposits is a critical parameter affecting the tendency for cracking of the deposits, and that niobium segregation plays a role in the cracking process. 


\subsection{Fireside Corrosion of Atmospheric-Fluidized Bed Combustor Tubes}

T. G. Godfrey and J. H. DeVan

We are continuing to examine sections of heat exchanger tubes that were exposed to the experimental atmospheric fluidized bed combustor operated by FluiDyne, Inc., of Minneapolis. Data for specimens exposed for $3000 \mathrm{~h}$ were reported last month, 1 and subsequent supplemental examination support the results given in that report. Examination of tubes exposed for times to $4500 \mathrm{~h}$ is in progress now.

\subsection{Failure Analysis and Prevention}

R. T. King

\subsubsection{Examination of Corrosion Coupons from Solvent Refined Coal Plants (R. T. King, V. B. Baylor, and R. S. Crouse)}

Metallographic examination of a set of corrosion coupons from the Fort Lewis, Washington, Solvent Refined Coal Plant, continued. Attempts to identify oxides or sulfides present in the scale on samples from the Wilsonville, Alabama, Solvent Refined Coal Plant by microprobe analyses were unsuccessful due to inability to distinguish oxygen using the new "light elements" equipment. However, sulfides can be identified directly, and the balance of the scale with high heavy metals content is presently assumed to be oxide. Confirmation by $x$-ray analyses will be performed.

\subsubsection{Analysis of Level Control Valve Seat from the Fort Lewis, Washington, Solvent Refined Coal Pilot Plant (V. B. Baylor)}

A final report on the cracked level control valve seat from the Fort Lewis, Washington, Solvent Refined Coal Plant, is in the process of publication.

\subsection{Materials for $\mathrm{ZnCl}_{2}$ Liquefaction Process Program}

J.R. Keiser and V. B. Baylor

Ceramics manufacturers are still being contacted to determine whether they have capabilities for providing commercial materials to contain the simulated $\mathrm{ZnCl}_{2}$ regeneration system environment. Materials which will be tested for their resistance to corrosion have been ordered and are being received. Testing facilities for this program as well as the equipment for the stress corrosion cracking program are under construction. 


\title{
3.6 Materials Research for Coal Liquefaction Program
}

\author{
V. B. Baylor and J. R. Keiser
}

Virtually all of the experimental materials for U-bend specimens have been received, welded, and fabricated into final form. Racks have been designed and constructed that are compatible with the Fort Lewis, Washington, and Wilsonville, Alabama, Solvent Refined Coal Plants. Racks of U-bend specimens for insertion in the Fort Lewis plant at the next shutdown, now scheduled for November 30, 1978, have been delivered to the plant site.

Visits were made to the Gulf Research Laboratory at Harmarville, Pennsylvania, and Exxon at Florham Park, New Jersey, to coordinate these activities with interested industrial parties.

\subsection{Development of Advanced $9 \mathrm{Cr}$-Mo Structural Steel}

R. J. Beaver and R. T. King

Three AOD heats of the advanced $9 \mathrm{Cr}$-Mo steel have been melted as a part of the Reactor Research and Technology Division's scaleup work, prior to ordering a $20-30$ ton heat to be funded by the Fossil Energy Division of DOE. A final agreement between DOE and TVA to permit exposure of the new steel in TVA commercial power boilers is essentially ready for signing. Two steelmakers have been contacted for initial reviews of the draft specification for the $20-30$ ton heat.

\subsection{Ceramic Recuperators (Heat Exchangers)}

V. J. Tennery and G. W. Webber

The preliminary design has been outlined for the modifications to be accomplished to the alternate fuel refractory test facility. These modifications will allow exposure testing of candidate ceramic recuperator materials to the off-gas stream characteristic of residual fuel use. The conceptual design will incorporate the ability to test up to 15 different tubes in either finned or smooth configurations with temperature and flow monitoring on primary and secondary sides and atmosphere analysis on the primary (exhaust) outlet side. The tentative final assembly and testing date at the present time is February 1979.

Subcontracts have been issued to Battelle Columbus Laboratory (Columbus, Ohio), Garrett-AiResearch (Torrance, California), and Warren Associates (Canoga Park, California) for recuperator survey and design studies. A meeting was held with Battelle Columbus Laboratory to outline the particulars of their survey which will address the potential for introduction of high temperature recuperators in steel soaking pits, 
aluminum remelt furnaces, and glass furnaces. Another meeting was held with Warren Associates to detail the assessment program of the relationship between potential future heat exchanger costs, capital investment requirements, and necessary manufacturing process improvements if ceramic heat exchangers are to become a marketable commodity. The third contract with Garrett-AiResearch will provide preliminary designs and cost analyses of ceramic heat exchangers for specific application in the steel, aluminum, and glass industries.

\subsection{References for Section 3}

1. I'. G. Godfrey and J. H. DeVañ, "Fireside Corrosion of AtmosphericFluidized Bed Combustor Tubes," Fossil Energy Program Report for September, 1978, 34-36, ORNL/TM-6630 (November 1978). 


\section{COAL EQUIPMENT TEST PROGRAM}

J. M. Holmes and R. E. MacPherson

Work under the Coal Equipment Test Program (CETP) is currently divided into three sections:

- Coal Feeder Test Program

- Survey of Industrial Capability for Coal Handling Equipment

- Fossil Fuel Dynamic Equipment Program Plan

\subsection{Coal Feeder Test Program}

B. T. Thompson and A. R. Sadlowe

\subsubsection{Coal Feeder Test Facility}

Work continued on the preparation of a feasibility study for a 5 ton per hour capacity facility to test one or more of the dry coal feeders being developed by DOE contractors. Various alternatives are being considered and cost estimates will be furnished.

Work completed this month included:

a. Presentation of formal design review to ORNL Coal Equipment Program personnel. Completion of the design report was approved.

b. Completion of plot plan and sectional elevations of feeder test building.

c. Acquisition of quotations on EP200 feeder Receiver (Simulated Reactor Vesse1).

d. Preparation of draft for Feasibility Study Report.

Work planned for next month:

a. Completion of draft for Feasibility Study Report.

b. Submission of draft and drawings to Conceptual Design Estimating

Department for estimating.

\subsection{Survey of Industrial Capability for Coal Handling Equipment}

F. C. Zapp, O. W. Thomas, M. D. Silverman

Questionnaires have been prepared for coal pulverizing, thermal drying equipment, grinders, delumpers, and crushing equipment used for breaking up slag from coal gasification reactors. 'l'wo copies of each questionnaire were sent to all known U.S. manufacturers of these types of equipment during September. 
Several questionnaires have been returned as of this report. Five replies have been received concerning the pulverizers, nine replies have been received covering the thermal dryers, and three replies related to the ash/slag crushing equipment.

Data compilation sheets were prepared to be utilized in recording all data provided in the returned questionnaires. A compilation of pertinent project documents was assembled, indexed, and forwarded to Mr. T. K. Lau of DOE.

Bechtel National, Inc., has started work on their subcontract which is entitled "Conceptual Flowsheets Development for Coal Conversion Plant Handling - Preparation and Ash/Slag Removal Operations". These conceptual flowsheets for both coal handling and ash/slag removal will:

a. Match the coal feed requirements (size consist and moisture) and ash/slag characteristics of conversion reactors used in selected major conversion processes being considered by DOE for development with emphasis on coal liquefaction processes.

b. Identify all equipment performance requirements.

c. Demonstrate how individual types of equipment are integrated to form complete, matched, efficient, reliable materials handling-preparation operations.

d. Allow identification of areas where equipment deficiencies exist or where improved or new equipment would be beneficial.

e. Be used to prepare equipment lists.

f. Identify operating conditions.

g. Provide power requirements.

Initial work on the coarse and fine coal handling task in this study was directed toward establishment of representative coal washability data for the coals under consideration, surveying of coal feed requirements and ash/slag conditions for the coal conversion processes specified, and initiation of block flowsheet development.

\subsection{Fossil Fuel Dynamic Equipment Program Plan}

All work on the Dynamic Equipment Plan has been discontinued pending redefinition of this activity by DOE Fossil Fuel Processing management. 


\section{ATMOSPHERIC FLUIDIZED BED COAL COMBUSTOR FOR COGENERATION (AFBCCC)}

R. S. Holcomb

\section{1 objective}

The Coal Combustor for Cogeneration (CCC) Program is directed at the development of a fluidized bed coal combustion system heating air inside tubes to provide high temperature clean air to drive a gas turbine to generate electricity. The heat in the air leaving the turbine exhaust would be recovered to supply industrial process heat. The gas turbine is very well suited for cogeneration since the ratio of thermal to electrical energy is about 3 to 1 for the gas turbine cycle as compared to a ratio of about 5 to 1 for a back-pressure steam turbine, and the exhaust heat from the gas turbine is available at a higher temperature. The scope of the program includes the study of industrial cogeneration plants in the size range from 5 to $50 \mathrm{MW}(e)$, and the construction and testing of a $0.3 \mathrm{MW}(\mathrm{e})$ technology test unit.

\subsection{Status Summary}

The draft of the request for proposal for the CCC program was revised as requested by DOE-FE and Mitre Corporation and was sent to DOE-FE on October 20. The revised draft is presently under review.

\subsection{Supplemental Studies}

The tubes from the corrosion test at FluiDyne have been received at ORNL. The appearance of the tubes is very good, with no indication of serious corrosion. Samples will be cut from the tubes for metallographic examination. 


\title{
6. ENGINEERING STUDIES AND TECHNICAL SUPPORT
}

\author{
R. W. Glass
}

Engineering studies and technical support are provided primarily for the DOE/FE Division of Fossil Fuel Processing. The effort includes: the development of analytical tools for use in the evaluation of processes and equipment; the technical and economic evaluation and comparison of coal conversion processes and subprocesses on a uniform basis; surveys of the need for coal conversion equipment and the capability of industry to provide such equipment; and studies of the magnitude and control of coal conversion plant emissions.

\subsection{Process Modeling}

R. Salmon, O. L. Culberson, and D. M. Lister

\subsubsection{Contract Objective}

The objective is to assist DOE/FE in its plan for computer analysis and computer support for coal conversion studies. This includes assistance to Purdue and Lehigh Universities in the development of computer programs for this plan. Physical property data are being collected and computerized primarily by Purdue and will be used in support of programs prepared by both universities. Purdue's general design program will aim at material and energy balances, equipment size and costing, plant capacity, and general economics. Lehigh's dynamic simulation programs will address plant design primarily from the standpoint of process performance during transient operations, but can also be used for steady-state conditions. A single flowsheet will be selected to assess the operability and complementary utility of both design programs.

\section{1 .2 Status Summary}

The latest version of the Purdue Mass Balance Program and associated documentation were received this month and have been processed to Librarian. About twenty modifications had to be made to successfully compile the code. Testing of the individual program examples supplied by Purdue is about to commence.

The latest documentation of the Purdue Energy Balance Program was received October 28, 1978, and we expect delivery of the code during the first week of November.

The Purdue Physical Properties Program and associated documentation were received during the third week of October. The code has been processed to Librarian and is currently being compiled. Some minor modifications were necessary in order for the BLOCK DATA routines to compile and testing of examples will start in November.

The Lehigh methanator model has been run in double precision. Results obtained are not significantly different from those obtained in the single precision run. 


\subsection{Coal Liquefaction Advanced Research Digest}

F. M. O'Hara, Jr, and R. W. Glass

\subsubsection{Contract Objective}

The objective is to provide continuing technical assistance to DOE/FE by preparing digest reviews of current or potential subjects relating to coal conversion technology.

\subsubsection{Status Summary}

Comments from the internal technical reviews of the final article (Fischer-Tropsch) for the second issue have been received, reviewed, and acted upon. Comments from DOE/FE were received late in the month, and the suggestions for changes and additions are being incorporated into the manuscript at this writing.

The literature search for and evaluation of information about the kinetics of coal hydrogenation and about the mechanisms of coal liquefaction have expanded into the journal literature. Another phase of literature searching - searching citation indexes under authors known to have published in this field - is about to begin. These comprise two of the three topics to be covered in the third issue of the Digest.

\subsection{Survey of Industrial Coal Conversion Equipment Capabilities}

W. R. Williams, T. M. Andress, W. F. Boudreau, W. A. Bush, D. W. Hatcher, J. R. Horton, W. R. Reed, C. B. Tolliver

\subsubsection{Contract Objective}

The objective of this project is to conduct surveys of industrial equipment capabilities that will identify the present capability of industry to supply the equipment needed. The project will also determine research and development needs, including lead time requirements, for producing equipment of advanced design for the various unit operations of critical importance to the Division of Fossil Fuel Processing.

\subsubsection{Status Summary}

The final draft report on mechanical connectors and expansion jointe was completed and sent to T. K. Lau un Octuber 13. The report on letdown valves is now being written.

Evaluation of pump prices is continuing to present difficulties. The computer programs being used to correlate these data are now working properly; however, price data are widely scattered. Compressor prices have been evaluated and seem to give reasonable results. These difficulties have caused some delay in completing the report on operating experience, prices, and development programs. 
J. R. Horton has evaluated the cost of various slurry charge pump systems using the 6000 tpd SRC demonstration plant operating conditions as a basis. In addition to using data supplied by vendors, he has received assistance from Ken Cook (Engineering Estimating Department) in developing total annual costs per on-stream, ideal horsepower required. Several additional factors are to be considered; however, pipe feeder and reciprocating pump feed systems already show significant cost advantages over centrifugal slurry pump systems of any type. The relative magnitude of the following costs is not expected to change significantly.

\begin{tabular}{|c|c|c|c|}
\hline System type & $\begin{array}{l}\Delta \mathrm{p} / \text { stage } \\
\quad(p s i)\end{array}$ & $\begin{array}{l}\text { Spare } \\
\text { capac1ey } \\
\quad(\%)\end{array}$ & $\begin{array}{l}\text { Cost/operating } \\
\text { horsepuwer } \\
\quad(\$ / \text { hp })\end{array}$ \\
\hline $\begin{array}{l}\text { Centrifugal - single- and } \\
\text { two-stage pumps - } \\
\text { current technology }\end{array}$ & 100 & 50 & 398 \\
\hline $\begin{array}{l}\text { Centrifugal - two-stage } \\
\text { pumps - high speed } \\
\text { "current" technology }\end{array}$ & 200 & $33-66$ & 336 \\
\hline $\begin{array}{l}\text { Centrifugal - two-stage - } \\
\text { high speed advanced } \\
\text { technology }\end{array}$ & 250 & 40 & 247 \\
\hline $\begin{array}{l}\text { Reciprocating pumps - } \\
\text { current practice }\end{array}$ & 2200 & $25-33$ & 189 \\
\hline $\begin{array}{l}\text { Reciprocating pumps - } \\
\text { "clean liquid end" }\end{array}$ & 2200 & 50 & 158 \\
\hline Pipe feeder & 2200 & 100 & $190^{*}$ \\
\hline \multicolumn{4}{|c|}{$\begin{array}{l}\text { * This cost would decrease to } \$ 165 / \text { hp in a full scale } 30,000 \text { tpd plant. } \\
\text { All other costs listed would remain constant. }\end{array}$} \\
\hline \multicolumn{4}{|c|}{$\begin{array}{l}\text { Pipe feeders operate somewhat like reciprocating pumps in that a long } \\
\text { pipe is used as a cylinder and a clean l1quld Is used as a piston. } \\
\text { Multistage centrifugal pumps operating on a clean liquid are used to } \\
\text { drive the slurry out of the pipe. }\end{array}$} \\
\hline
\end{tabular}




\subsection{Environmental Controls for Low-Btu Gasification}

S. P. N. Singh, M. S. Edwards, J. F. Fisher, G. R. Peterson, and R. Salmon

\subsubsection{Contract Objective}

The objective of this project is to evaluate the various environmental control processes that might be used in connection with. Low-Btu gasification facilities and to determine the economic tradeoffs for various processes and levels of control.

The project is divided into two phases: Phase I consists of Tasks 1 through 5 of the work statement, and covers the preparation of a detalled work plan and the selection of gasification and environmental control. processes for use in the study. Phase II consists of Tasks 6 through 8 in the work statement, and covers the collection and analysis of technical and economic data on the various environmental control processes and the preparation and analysis of flowsheets showing overall systems of environmental control processes used with various gasifiers.

\subsubsection{Status Summary}

A draft report on Task 8 titled Evaluation of Eight Environmental Control Systems for Low-Btu Coal Gasification Plants (ORNL-5481) has been prepared and is belng reviewed internally prior to dispatching the report to DOE/FE-Division of Systems Engineering. 


\section{PROCESS AND PROGRAM ANALYSIS}

R. W. Glass

Process and program analysis studies are being conducted for the DOE Fossil Energy Engineering Economics and Standards Section of the Systems Engineering Division. This effort includes research studies on most of the coal conversion and utilization processes. The program objective is to provide on a consistent basis, technical and economic evaluations of competing processes and systems for coal conversion and utilization.

\subsection{In Situ Coal Gasification}

M. S. Edwards and W. C. Ulrich

\subsubsection{Contract Objective}

The objective of this program is to provide technical and economic evaluations of candidate processes for the conversion of coal in situ to fluid products presently of interest. During FY 1977, technical and economic evaluations of the linked vertical well process applied to subbituminous coal were addressed. Three alternative end product configurations were considered - electricity, SNG, and syngas., In FY 1978, an evaluation is being conducted of an in situ facility for producing gasoline from methanol via the Mobil-M process.

\section{1 .2 Status Summary}

The draft report Evaluation of an In Situ Coal Gasification Facility for Producing M-Gasoline via Methanol, ORNL-5439, has been completed. The report contains:

a. Descriptions of process designs, including design assumptions and flow diagrams, developed for producing approximately 15,000 barrels per day of gasoline via methanol from in situ coal gasification.

b. Results of an economic analysis showing the product price of gasoline as a function of coal cost, rate of return on investment, and other technical and economic parameters.

c. Supporting data such as mass and utility balances, major equipment lists, capital and operating cost estimates, construction schedule, etc. 
The final estimates of M-gasoline product prices under various technical and economic assumptions were shown to vary from 0.81 to 1.34 \$/gal (33.85-56.19 \$/bbl.) Coal was $\$ 5 /$ ton (in place) and an annual after-tax rate of return on equity of $15 \%$ was assumed.

Copies of the draft report have been sent to the program manager in DOE, John Vlahakis, and are also being clrculated to interested parties in ORNL and elsewhere for review and comments.

\subsection{HYGAS Modeling}

J. P. Meyer, G. C. Frazier, J. W. Wells, and J. P. Belk

\subsubsection{Contract Objective}

The objective of this project is to develop a computer model of the HYGAS gasifier.

\subsubsection{Status Summary}

Appendices to the HYGAS final report, which include a documented listing of the Fortran source program and graphical results from both the IGT fluidized bed model and the completely backmixed single bed model, have been completed and distributed for internal review. However, because of other commitments, in-house review of both the final report and the appendices has been delayed. The review should be completed, revisions made, and the manuscript forwarded to DOE for comments by the end of November.

\subsection{Liquefaction}

R. W. Glass

\subsubsection{Contract Objective}

The objective of this project is to provide technical and economic evaluation of coal conversion liquefaction processes. Ralph M. Parsons Company is working under subcontract on the project with J. B. O'Hara as Project Manager. Major tasks included in the subcontract are: (1) a Survey of Liquefaction Processes, and (2) a Detailed Review of High Potential Liquefaction Processes.

\subsubsection{Status Summary}

Following review and discussion of the draft final reports for the liquefaction study:

1. Liquefaction Technology Assessment Final Report (Draft), ORNL/Sub-7186, The Ralph M. Parsons Company. 
2. Coalcon Process Review, R\&D Interim Report No. 3 (Draft), ORNL/Sub-7186-16, The Ralph M. Parsons Company.

it has been decided to extend and alter the existing subcontract in order to provide additional time for DOE/ORNL to fully coordinate desired report modifications. These modifications will result in (1) elimination of material related to the M-Gasoline process from the body of the report (with addition of the substance of this subject matter to the Appendix) and (2) further addition to the Appendix of estimated absolute economics for a base case process. The intent of this second change is to permit the reader to convert from the relative economics presented in the body of the report to projected absolute economics when and as desired.

It is estimated that report modifications, subsequent reviews, and publication/distribution can be completed by January 30, 1979 .

\subsection{High Btu Gas}

R. W. Glass

\subsubsection{Contract Objective}

This subprogram is being analyzed under subcontract by the Scientific Design Company, Incorporated (SD) with A. S. West as Project Manager. The present work is divided into three phases as follows:

1. The objective of Phase $I$ is to provide technical and economic evaluations of competing processes, concepts and systems for the production of high Btu gas from coal.

2. The objective of Phase II is to monitor and analyze data from the HYGAS Pilot Plant.

3. The objective of Phase III is to perform a technical and economical evaluation of the Battelle Agglomerating Ash Burner Process for the production of medium Btu fuel gas, synthesis gas and hydrogen from coal.

\subsubsection{Status Summary}

Monitoring of operations at the IGT HYGAS pilot plant in Chicago by SD engineers is continuing. Test Run No. 75 had to be aborted on October 6 , and the following information summarizes a report prepared by Scientific Design: 


\section{SUMMARY}

Test No. 75 started at 0130 hours on September 24, 1978, became self-sustained at 2310 hours on September 30,1978 , and was terminated in an orderly fashion at 0310 hours on October 6, 1978, because of a serious leak in the steam/oxygen supply line to the Gasifier. Because of the early termination none of the test objectives was achieved. The Test No. 75 objectives have been reassigned to Test No. 76 which was started on October 23, 1978. What little operating time was achieved was again plagued by problems in the solids handling, slurry feed and quench systems.

\section{TEST OBJECTIVES}

The principal objective of Test No. 75 was to approach the steamto-char ratio projected for the demonstration plant design ( 1.3 moles of steam per mole of carbon) at 900 PSIG operating pressure. A superficial velocity of $1.2 \mathrm{ft} / \mathrm{sec}$ was to be maintained by using nitrogen to supplement the steam feed.

The following target Gasifier conditions were established:

$\begin{array}{lr}\text { Operating pressure, psig, } & 900 \\ \text { Superficial velocity, ft/sec } & 1.2 \\ \text { Oxygen flow, lb/hr } & 1100 \\ \text { Max. SOG temperature, }{ }^{\circ} \mathrm{F} & 1775 \\ \text { Net char feed rate, TPH } & 2.0 \\ \text { Char conversion, \% } & 85\end{array}$

\begin{tabular}{|c|c|c|c|c|c|}
\hline$\underline{\text { PHASE }}$ & $\underline{I}$ & $\underline{\text { II }}$ & $\underline{\text { III }}$ & $\underline{\text { IV }}$ & $\underline{\mathrm{V}}$ \\
\hline$\frac{\text { Steam flow }}{1 \mathrm{~b} / \mathrm{hr}}$ & 9000 & 8100 & 7200 & 6300 & to be determined \\
\hline$\frac{\text { Nitrogen flow }}{1 \mathrm{~b} / \mathrm{hr}}$ & 0 & 1400 & 2800 & 4200 & to be determined \\
\hline
\end{tabular}

Phase 1 was to be further subdivided into four periods during which different sparger/stripping ratios would be investigated. This was requested by DOE during the Test No. 74 debriefing meeting.

\section{CONDUCT OF THE RUN}

Test Run No. 75 was conducted during a period of thirteen days beginning September 24, 1978. The run was interrupted after the initial light-off when erratic operation of the 321 transfer valve in the Gasifler required the unit to be depressurized and cooled before repairs could be made.

The second light-off occurred at 1158 hours on September 29 and since the Gasifier remained relatively warm from the previous 
period little time was required before the unit could be brought up to operating pressure and the oil feed and subsequent slurry feed could be started. Bed levels were established with little difficulty and the Gasifier became self-sustained at 2310 hours on. September $30,1978$.

Gasifier operation was fairly smooth from the time it became selfsustaining until October 3, 1978 when low char inventory resulting from a plugged lift line from the Coal Mill forced a reduction in the char feed rate to the Gasifier. Immediately after this change, solids flow through the Gasifier was lost interrupting the longest "smooth" period of the run (13.2 hours).

The only other "smooth" period (7.6 hours) started at 2100 hours on October 3, 1978 and ended at 0435 hours on October 4, $19 / 8$ when a leak in the low pressure slurry circulating loop and thick slurry in the system necessitated a reduction in char feed.

A major leak at the Greyloc connection for the steam-oxygen sparger was found on October 6 , and forced the termination of the test at 0310 hours.

The objective of reducing the steam flow to near the design rates projected for the demo plant, by replacing a portion of steam with nitrogen, was never achieved because of the early abortion of the run.

The post-run inspection revealed the presence of a small clinker (approximately 20 pounds) in the steam-oxygen bed. This clinker was in the immediate area of the connection for the steam-oxygen sparger and probably resulted from the oxygen leak. The minimum total steam to oxygen ratio during the test was 9.0 which was higher than that used during clinker free Test No. 74.

The operation of the Gasifier Effluent Cyclone and the Cyclone Dipleg Discharge Pot was erratic from very early in the run. A high elutriation rate must have occurred early because the quench system was plagued with problems from excessive solids after the first few days of the test.

No information on the gas quality is available. The two-hour reports do not give the quench product gas analyses for the "smooth" period from 1200 hours on October 2 to 0110 hours on October 3 . The second "smooth" period was less than eight hours duration so no analysis was made.

Test Run No. 76 (which started on October 24) is now in progress and will be described in the next monthly report. 


\subsection{Direct Combustion}

E. C. Fox and T. D. Anderson

\subsubsection{Contract objectives}

The purpose of this study program is to assist DOE/FE in their effort to develop a national strategy to increase the near-term use of coal through direct combustion; the applications of interest in this study are the small-to-moderate industrial user and the large residential/commercial user. The following objectives will be accomplished.

1. Identify and quantify the important factors restricting the use of coal in the sectors of interest.

2. Evaluate potential technological and institutional solutions to the problems identified in (1) above.

3. Make recommendations to DOE/FE relative to the most promising approaches to increasing the near-term use of coal.

\section{5 .2 Status summary}

The final reports are being prepared for publication.

\subsection{Advanced Power Conversion Systems \\ J. E. Jones Jr. and A. P. Fraas ${ }^{a}$}

\subsubsection{Contract objective}

The objectives of this project are to review selected major advanced power curiverston systems and to assess these systems with respect to their basic R\&D status.

\subsubsection{Status summary}

A total of eleven systems or components of systems were evaluated. Draft reports covering all of these topics, an overall summary report, and an executive summary report have been completed and are undergoing final review.

$a_{\text {Consultant }}$ 


\section{FOSSIL ENERGY ENVIRONMENTAL PROJECT}

C. R. Boston

The Fossil Energy Environmental Project provides the Division of Fossil Fuel Processing with program assistance in the performance of environmental assessment functions related to the expansion of fossil energy conversion technologies, performs assigned technical assistance tasks, and conducts programmatic environmental investigations that are critical to the early realization of advanced fossil energy technologies.

\subsection{Stured Solids Study}

W. J. Boegly, Jr.

The large shipment of Slagging Lurgi waste which was sent from Westfield, scotland, has been received at Baltimore, MD. We are currently attempting to obtain information from CONOCO about completing the shipment to ORNL. During October four 55-gal. drums of Pittshurgh \#18 coal and four 55-gal. drums of Western Kentucky \#9 were received at ORNL. These are the proposed feed coals for the CONOCO, Memphis, Grace/Ebasco, SRC-I, and SRC-II demonstration plants. We now have all the feed coal types for the DOE/FE demonstration projects.

The batch leaching procedures have been expanded to include the proposed EPA Toxicant Extraction Procedure (TEP), the two proposed ASTM leaching procedures, and leaching with $0.1 \mathrm{~N} \mathrm{HCl}$ and $0.1 \underline{\mathrm{N}}$ $\mathrm{NH}_{4} \mathrm{OH}$. The $0.1 \mathrm{~N}$ acid and alkaline leach give extremely high and low trace element concentrations, whereas, the TEP or ASTM will provide some indication of whether or not the solid waste would be considered "hazardous" using RCRA criteria.

Analysis of the data from the factorial leaching experiment have been initiated. All of the data have been keypunched on computer cards to simplify statistical analysis and plotting of the data. We plan to use the same data storage techniques for the laboratory and field leaching data. These techniques will allow computer generation of various data tables without the attendant typing and editorial work load. 


\title{
8.2 Technica1 Assistance
}

\author{
S. G. DeCicco
}

\subsubsection{Interaction with demonstration plant contractors}

SRC-I - The ORNL team visited the Newman, Kentucky, site on October 4 along with Dames \& Moore, Rust Engineering, Air Products, and DOE representatives. This trip was made in conjunction with the SRC-II site visit the day before. Following the site visit the staff once again reviewed Dames \& Moore's draft Environmental Impact Assessment (EIA) for the 2000 tpd facility, and the monitoring that has proceeded since the issuance of the draft. The purpose of the site visit and EIA review was to determine what, if any, additional monitoring was needed to support an adequate Environmental Impact Statement (EIS). Monitoring recommendations were sent to DOE-ORO on October 20 .

SRC-II - The ORNL team addressed itself to the task of developing a site- and process-specific baseline monitoring program for the SRC-II site in conjunction with Stearns-Roger, the environmental subcontractor for Gulf Mineral Resources Company (GMRC). On October 3 the team visited the Morgantown, West Virginia site with StearnsRoger, DOE-HQ, DOE-ORO, Mound Laboratory, and GMRC. Based on the information obtained during the site visit, recommendations were made on the scope of work proposed by Stearns-Roger. These recommendations were sent to DOE-ORO on October 20 .

ICGG - On October 25 a special meeting was called by DOE-HQ. The topic of discussion was Gibbs and Hill's (environmental subcontractor) response to "Geohydrology at the ICGG Site", a report prepared by ORNL. (See Monthly Report of August, 1978, for additional discussion.) The report outlined the current knowledge of the geohydrology of the site, all monitoring to date, environmental concerns at the site, and recommendations for further monitoring. At the meeting Gibbs and Hill discussed recent findings at the site which resolved some of the uncertainties. Additional monitoring was proposed by Gibbs \& Hill but largely rejected by ORNL because it was not judged to be cost-effective. The strategy for dealing with this topic will be to develop a thorough operational monitoring program to detect impacts in an effort to make up for. the lack of predictive capability.

At the meeting it was learned from DOE-HQ's project manager that the Environmental Report would not be delivered in final form until May, 1979. 
CONOCO - No activity this month.

MLGW - On October 5, ORNL participated in a meeting held at DOE-CHO to discuss a contract modification proposed to handle the current monitoring effort.

Grace/Ebasco - Based on all comments received on their original monitoring program, Ebasco/Envirosphere prepared a plan of study addendum. On October 12 a meeting was held at Envirosphere's offices in New York to discuss any further modifications to the addendum. Several recommendations were made by $\mathrm{DOE}-\mathrm{CHO}$, Mound Laboratory, and ORNL. As requested by DOE-CHO at the meeting, a formal statement of recommendations and rationale was prepared by ORNL and sent to DOE-CHO on October 26. Based on this statement, Ebasco will prepare a cost estimate for the additional work.

\subsection{Atmospheric Fluidized Bed Combustion Assessment}

S. G. DeCicco

Additional work was done to reduce the size of the environmental assessment to bring it more in line with the "summary" nature of the overall assessment. 


\section{MAGNETIC BENEFICIATION OF DRY PULVERIZED COAL}

E. C. Hise

\subsection{Objective}

The objective of this project is to develop and demonstrate a novel process for coal beneficiation by magnetic separation of pyrites and ash from dry pulverized coal.

\subsection{Status Summary}

Float-sink testing capability is being added to the laboratory. Glassware separators for 100-gram batches of less than 2-mm material have been installed, zinc chloride solutions of specific gravity 1.4 and 1.6 have been prepared, and a few trial runs made. Parallel and cross-separation tests will be performed to correlate the separation and Btu recovery of the magnetic and specific gravity separation methods.

A sample of fluidized bed boiler cyclone ash was sieved into size groups, magnetically separated into three fractions, and submitted for chemical analysis. The first magnetic fraction separated at a very low magnetic field strength; behaved as if ferromagnetic; and appeared under lilicruscoplc examination to be coke with reduced iron attached. The second magnetic fraction separated at a medium field strength; behaved as if strongly paramagnetic; and appeared to be coke plus some limestone. The non-magnetic fraction appeared to be mostly limestone. A sample of fluidized bed/boiler bed overflow was sieved to obtain a less than 30mesh portion, which was separated into four fractions on the basis of magnetic susceptibility. The most magnetic is dark brown; the less magnetic lighter brown and yellow; and the non-magnetic is cream to white with some coal.

$\Lambda$ purchase inquiry for a high gradient magnetic separation system is now in the hands of prospective vendors, and an order wil.1 probably be placed in November.

A fifty-pound sample of chemically comminuted coal and a fiftypound sample of the raw feed stock have been received for testing. It is proposed, when time permits, to mechanically crush the raw feed stock and test the relative separability of the chemically and mechanically comminuted coal.

The bulk. of the upflow tests at Sala have now been completed. The weight retention data and the preliminary chemical analyses indicate that, contrary to expectations, the downflow mode gave better separations than the upflow mode. The system is now being arranged for the fluidized bed mode, and these tests will probably be completed in November. Mr. Allen Holmon, who will join the program in late November, has started 
writing a computer program to analyze the Sala test data. There are approximately 1000 individual tests requiring calculation of Btu recovery, sulfur removal, and ash removal; of material balance for Btu, sulfur, and ash; and tabulated or plotted systematically. We will extend the Sala contract so that, following this analysis of the data, tests at the better conditions will be reperformed to demonstrate reproducibility of the experiment. 
10. AFBC BENCH SCALE MODEL

J. E. Jones, R. S. Holcomb, C. B. Smith, R. H. Guymon, and G. P. Zimmerman

\subsection{Objective}

The objective of the Bench Scale Model is to build and operate a small fluidized bed combustor. A test program is planned to obtain operating experience and data to support the design of a $200 \mathrm{MW}(\mathrm{e}) \mathrm{AFBC}$ steam electric power plant. The Bench Scale combustor is being built as a Seed Money project financed by ORNL discretionary funds.

\subsection{Progress to Date}

The combustor is $10 \mathrm{in.} O \mathrm{OD}$ and about $15 \mathrm{ft}$ tall. The bed and freeboard regions are enclosed in a transparent quartz glass housing to permit direct observation of the fluidized bed combustion process. The combustor is designed for burning 10 to $30 \mathrm{lb} / \mathrm{hr}$ of coal and is equipped for limestone addition. The system is designed to operate with a fluidizing velocity in the range of 4 to $10 \mathrm{ft} / \mathrm{sec}$ and bed temperatures up to $1600^{\circ} \mathrm{F}$. The bed is cooled by compressed air flowing through 0.5 in. OD tubes immersed in the bed. The air flow through the tubes will be maintained at a rate such that the maximum tube wall temperature will not exceed about $1100^{\circ} \mathrm{F}$ so that the temperature conditions will be comparable to those expected for superheater tubes in a fluidized bed steam generator.

The initial test program is planned to include hot air fluidization testing, coal combustion visualization, heat transfer, and short-term materials compatibility tests for bed temperatures up to $1600^{\circ} \mathrm{F}$. Beds composed of limestone with two mean particulate sizes, 1100 and $2000 \mu \mathrm{m}$, will be tested.

The installation of the combustor, combustion air system, flue gas systeill, and ash handling system was completed on November 1. Pिlexigias sleeves were installed in the combustor for cold air shakedown testing to be conducted before the quartz sleeves are installed. The quartz sleeve for the bed region has been received and the quartz sleeve for the freeboard was scheduled to be shipped on November 3 .

Shakedown testing was begun on November 1 . This will include system checkout, vibration tests with cold air flow through the empty combustor, air distributor plate pressure drop testing, and cold air fluidizing tests with a limestone bed.

Installation work is continuing to complete the discharge piping for the bed tube bundle cooling air, the line from the coal feeder to the combustor, and some of the instruments and controls including the flue gas oxygen analyzer and the timer controls for the bag filter 
cleaning air supply. It is expected that the remaining installation work will be completed by the middle of November, and hot air fluidization testing will be initiated in November. 


\section{TENNESSEE VALLEY AUTHORITY (TVA) FLUIDIZED BED COMBUSTION (FBC) DEMONSTRATION PLANT PROGRAM - TECHNICAL SUPPORT}

J. E. Jones Jr.

Tennessee Valley Authority has assumed a lead role in the demonstration of FBC technology for application in large utility boilers. ORNL will provide technical support and services to TVA in FBC systems. This work is to support TVA Energy Research's objective to develop FBC systems for utility electric power generation which will burn high sulfur coal and meet environmental emission standards.

TVA will be the lead agency in this work and will reimburse DOE for the work to be performed by ORNL. This work is to be conducted by ORNL under the terms and conditions of the Interagency Agreement between TVA, DOE, and ORNL regarding support for FBC research (reference: Agreement TV48296A, Subagreement 5).

\subsection{Impact of Revised New Source Performance Standards (NSPS) on AFBC Technology Development - Task 1}

J. E. Jones Jr., E. C. Fox, and R. E. Kuhlmann

\subsubsection{Contract objective}

To assist TVA in preparing a topical (White) paper that addresses the question as to whether atmospheric fluidized bed combustion can meet the proposed new source air emission standards and still be a viable option.

\section{i1.1.2 Status summary}

A draft paper has been prepared and is being reviewed and revised al buth TVA and ORNL. The paper coneludes that:

- AFBC technology can meet the new federal $\mathrm{SO}_{2}$ requirements of $85 \%$ removal and at lower costs than conventional pulverized fired boilers with scrubbers.

- AFBC solid wastes will be easier to dispose of than scrubber sludge and may be marketable as a soil additive or as building materials.

- Proposed particulate standards can be met with AFBC technology but fabric filters will probably be required (fabric filters probably will also be required for conventional boilers to meet the proposed standard). 
- Pilot plant data indicate that AFBC systems can meet the proposed NOx standards.

\author{
11.2 AFBC Technology Support - Task 2 \\ J. E. Jones Jr.
}

\title{
11.2.1 Contract objective
}

The objective of this program is to provide technical support of a general nature in $\mathrm{FBC}$ systems and respond to specific requests from TVA personnel. Such requests may include reviews, assessments, participation in TVA tasks, and similar activities.

\section{2 .2 Status summary}

The first two activities performed under this task are as follows:

1. Reviewed TVA (Assessment of AFBC: Steam Generator Designs) report FE-6013, dated June 1978, and evaluated this report. The ORNL letter report of this review is presented in Appendix 11.1 .

2. Review of B\&W's "Feasibility Analysis of a Conceptualized High Pressure Fluid Bed Boiler Design Development System" report. The ORNL letter report of this review is presented in Appendix 11.2.

\subsection{Assessment of the State-of-the-Art of}

PFBC Systems - Task 6

A. P. Fraas ${ }^{a}$, R. L. Graves, and M. E. Lackey

\subsubsection{Contract objective}

The purpose of this program is to provide TVA with an assessment and overview of the state-of-the-art for PFBC systems and their associated components.

\subsubsection{Status summary}

At the request of the Tennessee Va11ey Authority, a program has been initiated at ORNL to clarify the development status of pressurized fluidized bed combustion ( $P F B C$ ) technology and to place in perspective. the problems which are yet to be solved before commercialization of the concept is practical. The program consists primarily of surveys and technical evaluations of ongoing PFBC experimental development programs and recent PFBC design studies.

a Consult tant 
A preliminary report has been completed in draft form and is currently under review by TVA. This report includes a survey of PFBC experimental facilities, discussion of turbine erosion and hot gas cleanup, and a review of recent PFBC design studies. The key developmental problems emphasized in this preliminary report are envisioned as receiving more detailed attention in the program during FY 1979. 
APPENDIX 11.1

\section{OAK RIDGE NATIONAL LABORATORY \\ OPERATED BY \\ UNION CARBIDE CORPORATION \\ NUCLEAR DIVISION \\ 車 \\ POST OFFICE BOXY \\ OAK RIOGE, TENNESSEE 37830 \\ August 14, 1978}

Tennessee Valley Authority

440 Commerce Union Bank Building

Chattanooga, Tennessee 37401

Attention: Mr. Manville J. Mayfield, Program Manager

Combustion Systems

Gentlemen:

Review of TVA's Assessment of "Preliminary Steam

Generator Designs for an Atmospheric Fluidized Bed

Combustion Demonstration Power Plant" (EF-77-A-01-6013)

Attached are our collective comments resulting from a brief review of the subject report. The review incorporates coments from $S$. G. DeCicco, E. C. Fox, T. G. Godfrey, R. S. Holcomb, J. E. Jones Jr., R. E. KuhImann, and M. E. Lackey.

In general, we feel the TVA assessment provides a fair evaluation of the three boiler manufacturers' designs. Please let. me, know if we can be of further service.

JEJ : js

Sincerely yours,<smiles>CC12CCCCC1CCC2</smiles>

John E. Jones Jr:

Fossil Energy Program Manager

Engineering Technology Division

Attachment

cc: J. M. Castleberry, TVA

J. Fourroux, TVA

$a$

L. E. Nicicese

W. Newherry, TVA

H. W: Withers, TVA 


\section{Review of TVA's Assessment of "Preliminary Steam Generator Design for an AFBC Demonstration Power Plant"}

Overall we feel the TVA assessment. provides a fair evaluation of the three designs. We concur that a large bed pilot plant should be built to test coal feed, control, and turndown. The areas of needed R\&D are agreed to be vital for the success of the AFBC demonstration plant. The four major areas of uncertainty (materials feed and distribution, bed design and performance, control of start-up and load following, and materials of construction) are in agreement with main issues that our assessment is developing. However, we feel another major area of uncertainty, where additional research and development is necessary, is the heat transfer data base for optimizing heat transfer surface area and developing control techniques.

Comments on. specific items of the report are as follows.

1. The FCC overbed feed system, which uses coal with a top size of $1-1 / 4$ in coupled with one bed drain per $220 \mathrm{ft}^{2}$, has the potential for large "rocks" to accumulate in the lower regions of the bed. These large "rpcks" would be in a nonfluidized condition and could eventually interfere with the heat transfer bundles located in the bed.

2. The operation of the $\mathrm{CBC}$ requires various conditions as follows: for CE design, $2000^{\circ} \mathrm{F}$ with in-bed tubes; for FCC design, $1850^{\circ} \mathrm{F}$ with in-bed tubes; and for $B \& W$ design, $2000^{\circ} \mathrm{F}$ with only waterwall tubes.

It is doubtful that existing materials can withstand the environment of $\mathrm{CE}$ and FCC designs. B\&W design provides a conservative viewpoint and may be appropriate. This brings up a general item of concern that there are no corrosion/erosion data on tube metals at these high temperature conditions. There docs not seem to be a corrosion allowance for these tubes immersed in the CsC.

3. The environmental emissions for AFBC operation are mentioned in the evaluation of the three boiler manufacturers' designs. However, the lack of emission rates and level of pollutants seems to be a 
significant omission. The evaluation of the hardware for control of emissions appears to be emphasized more than the process control of these emissions.

4. The economic comparison of capital costs for the three boiler manufacturers' designs with that of a conventional coal-fired utility boiler with wet scrubber is based on the boiler only and not a complete power plant. The resulting conclusions from the economic comparison to the conventional coal-fired boiler with wet scrubber are. somewhat more favorable to AFBC in terms of percentage cost difference than if the comparison were based on total plant costs.

5. The need for demonstration of in-bed reheat in the demo plant is not clear. The wide range of fluidizing superficial velocities for the combustors is not compared to indicate the best conditions.

6. The limited knowledge from pilot unit studies in the critical areas li.e., control, fuel feeding, heat transfer coefficients, collection of elutriates from fluidized beds) needs to be brought forth as an important qualification to the whole comparison of the full-scale plant designs.

7. The lack of adequate corrosion data needs to be emphasized. Work is needed to obtain long-term corrosion data to establish life of the tubes (especially superheater tubes) which may considerably affect the economic advantage of fluidized bed combustion:

8. The B\&W design seems to use all the excess air to transfer coal to the feeders. This may result in reducing conditions away from the feeder points.

9. The freeboard height in the $B \& W$ design ( 4 to $5 \mathrm{ft}$ ) may be too low and, therefore, risk excessive elutriation even for the low velocity (4 fps).

10. Separate limestone feed does appear to be a worthwhile simplification. However, bccause of the normally smaller particle size and the potential for excessive elutriation, we would question the conclusion that limestone feed should be overbed. 
APPENDIX 11.2

\section{OAK ridge national laboratory \\ OPERATED OY \\ UNION CARBIDE CORPORATION \\ NUCLEAR DIVISION}

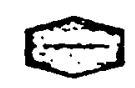

POST OFFICE BOX $Y$

OAK RIDLE. IENNESSEE 37830

September 11, 1978

Tennessee Valley Authority

440 Commerce Union Bank Building

Chattanooga, Tennessee 37401

Attention: Mr. Manville J. Mayfield, Program Manager: Combustion Systens

Gentlemen:

Review of Bsin's "Feasibility Analysis of a Conceptualized High Pressure Fluid Bed Boiler Design Development s;stem"

A $6 \times 22$-ft AFBC Pilot Plant is most reasonable and desirable. We conclude that B\&W has effectively considered most aspects and potential. problem areas for the design.

In general, we feel that a pilot plant of the size proposed will fill a gap between existing small-scale test.facilities and the proposed 200 Mre demonstration plant. Significant areas of investigation for which this facility is uniquely suitable include turndown control and coal feeding. Data on materials compatability, combustion efficiency, and sulfur capture. will also be very important in view of the large bed area and the similarity to utility operating conditions.

Our overriding concern is that the pilot plant provide the required data base for an $A F B C$ demonstration plant. Both the design and projram (operating) plan should fosus on this objective. We reconnend that a preliminary program plan addressing the critical problem areas (materials, coal Eecding, turndoin control, etc.) be develoned as a basis for juiting the deșign in terms of instrumentation, material testing; and coal feed flexibility. 
A number of specific coments are attached. Contributors include H. D. Cochran, T. G. Godfrey, R. S. Holcomb, J. E. Jones Jr., R. E. Kuhlmann, M. E. Lackey, and C. B. Smith. We will be pleased to discuss these coments in detail at your convenience.

JEJ : js

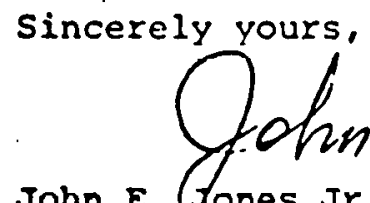

John E. Wones Jr. Fossil Energy Program Manager

cc: J. M. Castleberry, TVA

J. Fourroux, TVA

L. E. MaNeese

W. -Newberry, TVA

H. W. Withers, TVA

Attachment 
Comments

1. Coal Feeding - Coal and limestone feeding at $9.43 \mathrm{ft}^{2}$ per feed point represents a conservative state-of-the-art design. We concur with this approach but feel flexibility to reduce the number of feed points to cover, say, $36 \mathrm{ft}^{2}$ should be incorporated. Provision for testing overbed spreader feeders should also be considered.

2. Coal Transport Air Flow - The B\&W coal feed system uses 208 of the combustion air in the coal transport lines to the bed. The design calls for only 158 excess air in the main bed, which could lead to reducing conditions at the points sarthest anay from the coal feed ports.

3. Design of Segmented Eed - No partition wall is shown between the start-lip bed and the tubed boiler and superheater operating bed region. This may lead to difficulties during start-up. Without a wall, it may not be possible to build the hot, fluidized start-up bed to a greater depth thin the coal bed being started. The small inventory available from the start-up bed with a reduced level may lead to a very slow start-up and possibly to bed quenching problems as the level is gradually raised in the tube bundle. It is suggested that consideration be given to providing a refractory partition wall, with a connecting opening near the bottom, between the start-up bed and the main bed. This would permit the start-up bed to be heated and raised to a high level and provide a larger inventory of hot solids to transier to trie cold bed. Wher tine cold bed is fluidized, the levels would equalize through the opening in the wall. A wall between each operating segments of the main bed might prove to be beneficial for the sane reasons.

4. Sampling and analysis of the gaseous ( $\mathrm{NO}_{\mathrm{x}^{\prime}} \mathrm{SO}_{2}, \mathrm{SO}_{3}, \mathrm{CO}_{2}$, and $\mathrm{CO}$ ) and particulate effluents should be included in the bed, in the frccboard, and along the flue gas path to the stack.

5. Heat recovery from spent bed material will be necessary in a commercial plant. This unproven technology should be tested in the design development system.

6. Controls and instrumentation for BSi's scope of supply for the pilot plant need to be more fully described. These may prove to be inadouate to fulfill the SSD objectives of the design develo:ment system.

7. In the area of materials, Bsw has used utility-common technolory with provisions for incorporating uncommon matcrials when and where warranted (hangers, supports, distributor plates, tube. bundles, etc.). A nore datailed invistigation and analysis may

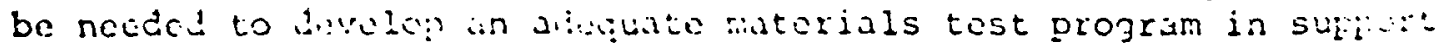
of the 200 rid demonstration plant. 
THIS PAGE

\section{WAS INTENTIONALLY \\ LEFT BLANK}


INTERNAL DISTRIBUTION

1. S. I. Auerbach

2. V. B. Baylor

3. M. Bender

4. W. J. Boegly

5. C. R. Boston

6. R. A. Bradley

7. J. I. Brand

8. C. H. Brown

9. G. H. Burger

10. J. E. Campbe11

11. D. A. Canonico

12. J. A. Carter

13. B. R. Clark

14. H. D. Cochran, Jr.

15. E. Copenhaver

16. K. E. Cowser

17. R. M. Davis

18. M. S. Denton

19. D. G. Doherty

20. M. S. Edwards

21. D. M. Eissenberg

22. J. L. Epler

23. D. E. Ferguson

24. L. M. Ferris

25. J. F. Fisher

26. R. C. Forrester III

27. E. C. Fox

28 W. Fulkerson

29. E. L. Fuller

30. W. R. Gambill

31. R. B. Gammage

32. D. A. Gardiner

33. T. M. Gilliam

34. R. W. Glass

35. T. G. Godfrey

36. W. L. Greenstreet

37. M. R. Guerin

38. C. W. Hancher

39. L. A. Harris

40. S. E. Herbes

41. J. R. Hightower

42. E. C. Hise

43. R. S. Holcomb

44. J. M. Holmes

45. J. K. Huffstetler

46. G. R. Jasny

47. R. L. Jolley

48. J. E. Jones, Jr.

49. 0. L. Keller
50. R. T. King

51. J. A. Klein

52. R. L. Kroodsma

53. J. W. Larsen

54. R. S. Livingston

55. R. E. MacPherson

56. A. P. Malinauskas

57. G. B. Marrow

58. C. J. McHargue

59-63. L. E. McNeese

64. J. P. Meyer

65. J. E. Mrochek

66. P. Nettesheim

67. J. P. Nichols

68. B. Niemann

69. L. C. Oakes

70.. G. E. Oswald

71-72. T. W. Pickel

73. W. W. Pitt

74. H. Postma

75. M. L. Poutsma

76. D. E. Reichle

77. C. R. Richmond

78. B. R. Rodgers

79. M. W. Rosenthal

80. R. H. Ross

81. T. H. Row

82. W. L. Russell

83. R. Salmon

84. G. Samuels

85. C. D. Scott

86. W. D. Shults

87. M. Siman-tov

88. S. P. N. Singh

89. C. B. Sm1th

90. G. P. Smith

91. I. Spiewak

92. R. L. Spore

93. J. B. Storer

94. R. A. Strehlow

95. 0. K. Tallent

96. I. L. Thomas

97. J. R. Thurgood

98. H. E. Tranunell

99. D. B. Trauger

100. W. C. Ulrich

101. R. I. Van Hook

102. P. R. Vanstrum

103. J. S. Watson 
104. J. R. Weir

105. P. R. Westmoreland

106. M. K. Wilkinson

107. L. V. Wilson

108. R. G. Wymer

109. E. L. Youngblood

110. C. S. Yust
111. H. W. Sternberg (Consultant)

112. Patent office

113-120. Laboratory Records

121. Laboratory Records - RC

122-124. Central Research Library

125. Document Reference Section

EXTERNAL DISTRIBUTION

DOE-Oak Ridge Operations

126. Assistant Manager, Office of Energy Research and Development, DOE-ORO

DOE-Denver Project Office, Suite 211, 1075 S. Yukon Street, Lakewood, CO 80226

127. W. L. No11

DOE-Office of Fossil Energy, Germantown, MD

128. W. T. Bakker

129. E. K. Bastress

130. J. D. Batchelor

131. T. Beresovski

132. L. M. Burman

133. E. L. Burwe 11

134. N. P. Cochran

135. R. C. Corey

136. T. B. Cox

137. C. W. De Be11a

145. L. Kindley

146. C. W. Knudsen

147. T. K. Lau

148. E. Lievens

149. C. Miller

150. M. B. Neuworth

151. E. S. Pierce

152. H. E. Poda11

138. R. H. Fischer

153. J. L. Powell

139. J. Forst

154. M. Reilly

155. J. Shen

140. H. Franke1

156. A. P. Sikri

141. S. I. Freedman

157. J. Smith

142. W. S. Harmon

158. D. K. Stevens

143. H. Jones

144. L. M. Joseph

159. W. E. Warnke

160. J. W. Watkins

161. H. L. Weisenfeld

162. P. R. Wieber

DOE-Environment, Washington, DC

163. N. F. Barr:

164. R. M. Jimeson

165. W. E. Mott

166. R. W. Wood

Department of Housing and Urban Development, 451 th St., S.W., Washington, DC 20410

167. G. S. Leighton

168. J. H. Rothenberg

National Science Foundation, 1800 G Street, N.W., Washington, DC 20550

169. Robert Rabin 
Tennessee Valley Authority, 1230 Commerce Union Bank Building, Chattanooga, TN 37401
170. J. M. Castleberry
171. Randy M. Cole
172. Barry Goss
173. G. A. Hollinden
174. Manville J. Mayfield
175. Stephen R. Smith
176. Donald C. Thomas
177. Uwe Zitzow

University of Kentucky, Institute for Mining and Minerals Research, 213 Bradley Hall, Lexington, KY 40506

178. Theresa Wiley, Institute Librarian

179. 0. J. Hahn

180. J. K. Shau

181. Seymour Alpert, Manager, Process Development Fossil Fuel Department, Electric Power Research Institute, 3412 Hillview Ave., P. 0. Box 10412, Palo Alto, CA 94304

182. Frank Baranowski, Mechanical Technology Incorporated, Crysta1 Square 4, Suite 310, Jefferson Davis Highway, Arlington, VA 22202

183. Gary L. Baughman, Cameron Engineers, 1315 South Clarkson St., Denver, CO 80213

184. Harold Beuther, Manager, Catalyst and Chemicals Research, Gulf Research and Development Company, P. O. Box 2038, Pittsburgh, PA 15230

185. William R. Epperly, Exxon Research and Engineering Company, P. 0. Box Florham Park, NJ 07932

186. Jack L. Gregory, Project Manager, TRW Energy Systems,, 7600 Colshire Drive, McClean, VA 22101

187. Martha Koehler, Bechtel Corp., P. O. Box 3695, San Francisco, CA 94119

188. Robert W. Laza, Director, Interim Project Office, Department of Energy, Chicago Operations Office, 9800 S. Cass Avenue, Argonne, IL 60439

189. W. J. Lochmann, Ralph M. Parsons Co., 100 W. Walnut Street, Pasadena, CA 91124

190. WaIter Mc.Gough, Jr., Tetra Tech, Inc., 1911 N. Ft. Myer Drive, Suite 601, Arlington, VA 22209

191-196. Morgantown Energy Technology Center, P. O. Box 800, Morgantown, WV 26506, ATTN: The Director

197. Thomas E. O'Hare, Department of Energy and Environment, Brookhaven National Laboratory, Associated Universities, Inc., Upton, LI, NY 11973

198. F. N. Peebles, Dean of Engineering, University of Tennessee, Knoxville, TN 37916 
199. Kenneth P. Lue Phang, Development Engineering Staff, Tennessee Valley Authority, 220 Liberty Building, Knoxville, TN 37902

200-211. Pittsburgh Energy Technology Center, ATTN: Director for J. O. Barreca, 4800 Forbes Ave., Pittsburgh, PA 15213

212. Charles B. Sedman, U.S. Environmental Protection Agency, Research Triangle Park, NC 27711

213. Dr. Marion Semchyshen, Director of Research, Materials Research for Molybdenum Development, Climax Molybdenum Research Laboratory, 1600 Huron Parkway, P. 0. Box 1568, Ann Arbor, MI 48106

214. W. R. Siegart, Texaco Inc., 2000 Westchester Ave., White Plains, NY 10650

215. Carl Streed, Process Research and Development Division, Mobil Research and Development Corporation, Billingsport Road, Paulsboro, NJ 08066

216. Dr. Wende1l. Wiser, Department of Mining and Fuels Engineering, University of Utah, Salt Lake City, UT 84112

217-243. Technical Information Center. 